\title{
\#USGS
}

Prepared in cooperation with the

New York State Department of Environmental Conservation

\section{Groundwater Quality in Central New York, 2007}
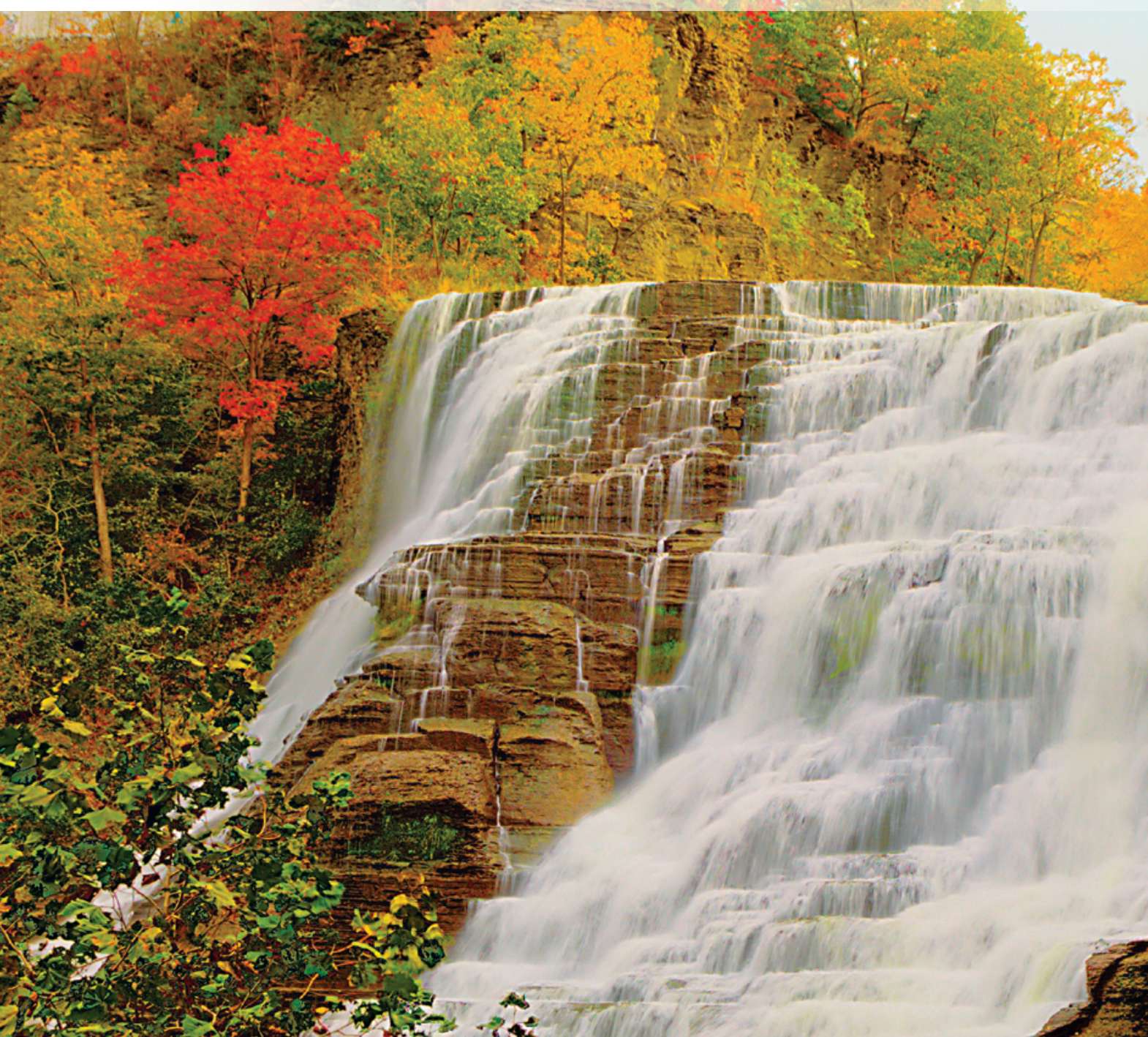

$$
\text { का }
$$
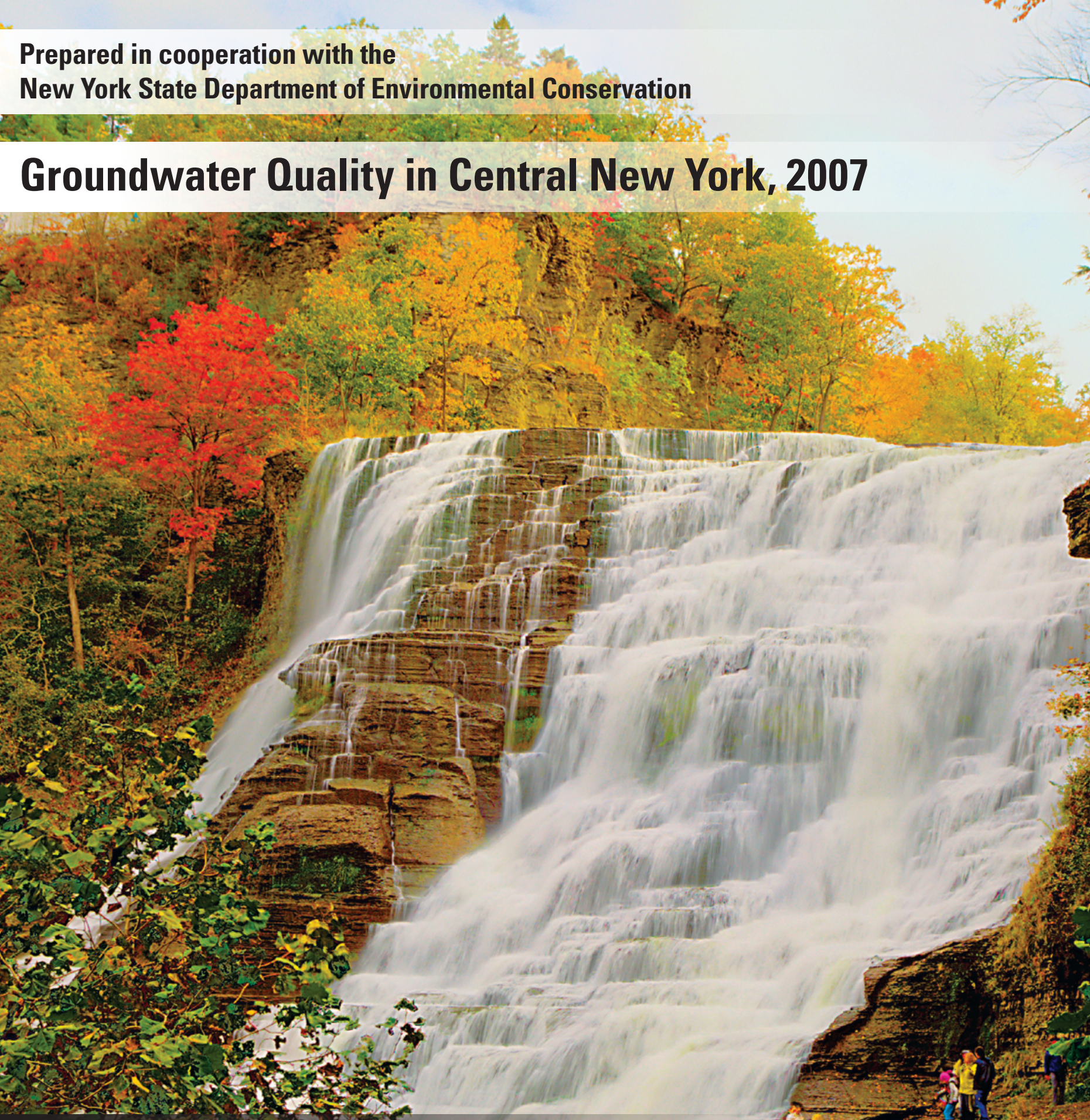

Open-File Report 2009 1257 
Cover: Ithaca Falls on Fall Creek in the City of Ithaca is typical of the scenic gorges of the Finger Lakes region in central New York. (Photo by Larry Twostep Mah.) 


\section{Groundwater Quality in Central New York, 2007}

By David A.V. Eckhardt, J.E. Reddy, and Stephen B. Shaw

Prepared in cooperation with the

New York State Department of Environmental Conservation

Open-File Report 2009-1257 


\section{U.S. Department of the Interior KEN SALAZAR, Secretary}

\section{U.S. Geological Survey Marcia K. McNutt, Director}

U.S. Geological Survey, Reston, Virginia: 2009

For more information on the USGS-the Federal source for science about the Earth, its natural and living resources, natural hazards, and the environment, visit http://www.usgs.gov or call 1-888-ASK-USGS.

For an overview of USGS information products, including maps, imagery, and publications, visit $h$ ttp://www.usgs.gov/pubprod

To order this and other USGS information products, visit http://store.usgs.gov

Suggested citation:

Eckhardt, D.A., Reddy, J.E., and Shaw, S.B., 2009, Groundwater quality in central New York, 2007: U.S. Geological Survey Open-File Report 2009-1257, 38 p., available online at http://pubs.usgs.gov/of/2009/1257.

Any use of trade, product, or firm names is for descriptive purposes only and does not imply endorsement by the U.S. Government.

Although this report is in the public domain, permission must be secured from the individual copyright owners to reproduce any copyrighted material contained within this report. 


\section{Contents}

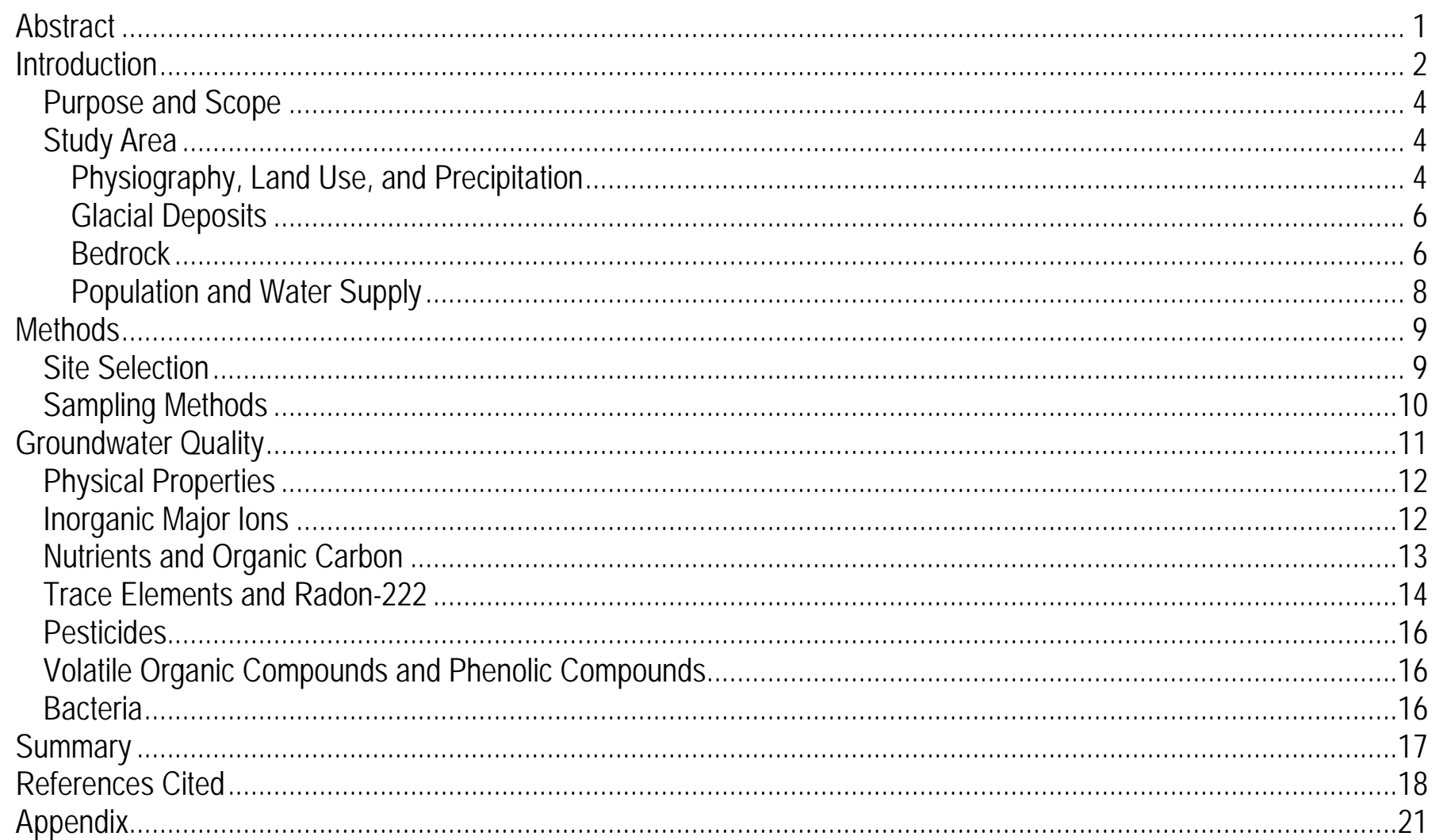

\section{Figures}

Figure 1. Maps showing pertinent geographic features of study area in central New York, and locations of the 35

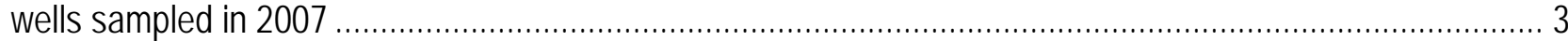

Figure 2. Map showing land use in central New York study area and locations of the 35 wells sampled in $2007 \ldots \ldots . . .5$

Figure 3. Map showing generalized surficial geology of central New York study area and locations of the 17 wells

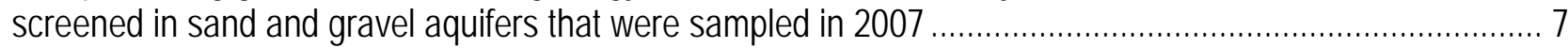

Figure 4. Map showing generalized bedrock geology of central New York study area and locations of the 18 wells completed in bedrock that were sampled in 2007.

\section{Tables}

Table 1. Basin areas and population of the central New York study area, by drainage basin

Table 2. Summary statistics for concentrations of major ions in sand and gravel aquifers and bedrock aquifers in central New York, 2007

Table 3. Summary statistics for concentrations of nutrients and organic carbon in sand and gravel aquifers and bedrock aquifers in central New York, 2007

Table 4. Summary statistics for concentrations of trace elements and radon-222 in sand and gravel aquifers and bedrock aquifers in central New York, 2007 


\section{Tables at end of report:}

Table A1. Description of wells sampled in the central New York study area, 2007

Table A2. Compounds for which groundwater samples collected from wells in the central New York study area

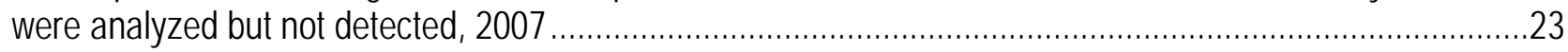

Table A3. Physical properties of groundwater samples from the central New York study area, 2007.......................27

Table A4. Concentrations of inorganic constituents in groundwater samples from the central New York study area, 2007

Table A5. Concentrations of nutrients and total organic carbon in groundwater samples from the central New York study area, 2007

Table A6. Concentrations of trace elements and radon-222 in groundwater samples from the central New York study area, 2007.

Table A7. Concentrations of pesticides detected in groundwater samples from the central New York study area, 2007 .....

Table A8. Concentrations of volatile organic compounds in groundwater samples from the central New York study area, 2007.

Table A9. Concentrations of bacteria in unfiltered groundwater samples from the central New York study area, 2007 


\section{Conversion Factors, Abbreviations, and Datums}

\begin{tabular}{lll}
\hline \multicolumn{1}{c}{ Multiply } & \multicolumn{1}{c}{ By } & \multicolumn{1}{c}{ To obtain } \\
\hline inch (in) & 2.54 & centimeter $(\mathrm{mm})$ \\
foot (ft) & 0.3048 & meter $(\mathrm{m})$ \\
square mile $\left(\mathrm{mi}^{2}\right)$ & 2.590 & square kilometer $\left(\mathrm{km}^{2}\right)$ \\
million gallons per day (Mgal/d) & 0.04381 & cubic meter per second $\left(\mathrm{m}^{3} / \mathrm{s}\right)$ \\
\hline
\end{tabular}

Temperature in degrees Celsius $\left({ }^{\circ} \mathrm{C}\right)$ may be converted to degrees Fahrenheit $\left({ }^{\circ} \mathrm{F}\right)$ as follows:

$$
{ }^{\circ} \mathrm{F}=\left(1.8 x^{\circ} \mathrm{C}\right)+32 \text {. }
$$

\section{Abbreviations}

AMCL

Alternative maximum contaminant level

$\mathrm{CFU} / \mathrm{mL}$

Colony forming units per milliliter

CIAT

2-Chloro-4-isopropylamino-6-amino-s-triazine (also called deethylatrazine)

CWS

Community water system

ESA

Ethanesulfonic acid

HA

Health Advisory for drinking water

HPC

Heterotrophic plate count

MCL

Maximum Contaminant Level

MTBE

Methyl tert-butyl ether

NWQL

USGS National Water Quality Laboratory

NYSDEC

New York State Department of Environmental Conservation

NYSDOH

New York State Department of Health

$O A$

Oxanilic acid

OGRL

USGS Organic Geochemistry Research Laboratory

OIET

2-Hydroxy-4-isopropylamino-6-ethylamino-s-triazine (also called hydroxyatrazine)

SMCL

Secondary Maximum Contaminant Level

USEPA U.S. Environmental Protection Agency

USGS

U.S. Geological Survey

VOC Volatile organic compound

Other abbreviations in this report

micrometer $(\mu \mathrm{m})$

micrograms per liter $(\mu \mathrm{g} / \mathrm{L})$

milligrams per liter $(\mathrm{mg} / \mathrm{L})$

microsiemens per centimeter $(\mu \mathrm{S} / \mathrm{cm})$

platinum-cobalt units (Pt-Co units)

picocuries per liter ( $\mathrm{pCi} / \mathrm{L})$

\section{Datums}

Vertical coordinate information is referenced to the National Geodetic Vertical Datum of 1929 (NGVD 29).

Horizontal coordinate information is referenced to the North American Datum of 1983 (NAD 83). 
This page intentionally left blank. 


\title{
Groundwater Quality in Central New York, 2007
}

\author{
By David A.V. Eckhardt, J.E. Reddy, and Stephen B. Shaw
}

\section{Abstract}

Water samples were collected from 7 production wells and 28 private residential wells in central New York from August through December 2007 and analyzed to characterize the chemical quality of groundwater. Seventeen wells are screened in sand and gravel aquifers, and 18 are finished in bedrock aquifers. The wells were selected to represent areas of greatest groundwater use and to provide a geographical sampling from the 5,799-square-mile study area. Samples were analyzed for 6 physical properties and 216 constituents, including nutrients, major inorganic ions, trace elements, radionuclides, pesticides, volatile organic compounds, phenolic compounds, organic carbon, and 4 types of bacteria.

Results indicate that groundwater used for drinking supply is generally of acceptable quality, although concentrations of some constituents or bacteria exceeded at least one drinking-water standard at several wells. The cations detected in the highest concentrations were calcium, magnesium, and sodium; anions detected in the highest concentrations were bicarbonate, chloride, and sulfate. The predominant nutrients were nitrate and ammonia, but no nutrients exceeded Maximum Contaminant Levels (MCLs). The trace elements barium, boron, lithium, and strontium were detected in every sample; the trace elements present in the highest concentrations were barium, boron, iron, lithium, manganese, and strontium. Fifteen pesticides, including seven pesticide degradates, were detected in water from 17 of the 35 wells, but none of the concentrations exceeded State or Federal MCLs. Sixteen volatile organic compounds were detected in water from 15 of the 35 wells.

Nine analytes and three types of bacteria were detected in concentrations that exceeded Federal and State drinking-water standards, which typically are identical. One sample had a water color that exceeded the U.S. Environmental Protection Agency (USEPA) Secondary Maximum Contaminant Level (SMCL) and the New York State MCL of 10 color units. Sulfate concentrations exceeded the USEPA SMCL and the New York State MCL of 250 milligrams per liter $(\mathrm{mg} / \mathrm{L})$ in two samples, and chloride concentrations exceeded the USEPA SMCL and the New York State MCL of $250 \mathrm{mg} / \mathrm{L}$ in two samples. Sodium concentrations exceeded the USEPA Drinking Water Health Advisory of $60 \mathrm{mg} / \mathrm{L}$ in eight samples. Iron concentrations exceeded the USEPA SMCL and the New York State MCL of 300 micrograms per liter $(\mu \mathrm{g} / \mathrm{L})$ in 10 filtered samples. Manganese exceeded the USEPA SMCL of $50 \mu \mathrm{g} / \mathrm{L}$ in 10 filtered samples and the New York State MCL of $300 \mu \mathrm{g} / \mathrm{L}$ in 1 filtered sample. Barium exceeded the MCL of 2,000 $\mu \mathrm{g} / \mathrm{L}$ in one sample, and aluminum exceeded the SMCL of $50 \mu \mathrm{g} / \mathrm{L}$ in three samples. Radon-222 exceeded the proposed USEPA MCL of 300 picocuries per liter in 12 samples. One sample from a private residential well had a trichloroethene concentration of $50.8 \mu \mathrm{g} / \mathrm{L}$, which exceeded the MCL of $5 \mu \mathrm{g} / \mathrm{L}$. Any detection of coliform bacteria indicates a potential violation of New York State health regulations; total coliform bacteria were detected in 19 samples, and fecal coliform bacteria were detected in one sample. The plate counts for heterotrophic bacteria exceeded the MCL (500 colonyforming units per milliliter) in three samples. 


\section{Introduction}

Water samples were collected from 7 production wells and 28 private residential wells in 18 counties in central New York from August through December 2007 and analyzed to characterize the chemical quality of groundwater in the 5,799- $\mathrm{mi}^{2}$ study area. Thirty-one wells are within the Oswego River Basin (which contains the Seneca and Oneida River Basins), and four are in the central Lake Ontario Basin, which drains the area between Oswego and Rochester (fig. 1). Seventeen of the wells are screened in sand and gravel aquifers, and 18 are completed in bedrock aquifers.

Many studies of groundwater quality in New York have included parts of the study area, such as Weist and Geist (1969), Kantrowitz (1970), Crain (1975), Cartwright and Ziarno (1980), Waller and Finch (1982), Cosner (1984), and Yager and others (2007). These studies provide much useful information, but a more comprehensive and current assessment of the groundwater quality throughout the entire area is needed.

Section 305(b) of the Federal Clean Water Act Amendments of 1977 (U.S. Environmental Protection Agency, 1997) requires all States to implement a comprehensive water-quality-monitoring program for surface-water and groundwater resources. In 2001, the U.S. Geological Survey (USGS), in cooperation with the New York State Department of Environmental Conservation (NYSDEC) and the U.S. Environmental Protection Agency (USEPA), began an assessment of groundwater quality in major river basins throughout the State, as specified in Section 305(b). To date (2008), groundwater-quality studies have been completed in the Chemung River Basin (Hetcher-Aguila, 2004), the Lake Champlain Basin (Nystrom, 2006), the upper Susquehanna River Basin (Hetcher-Aguila and Eckhardt, 2006), the Delaware River Basin (Nystrom, 2007a), the St. Lawrence River Basin (Nystrom, 2007b), the Genesee River Basin (Eckhardt and others, 2007), the Mohawk River Basin (Nystrom, 2008), and three drainage basins in western New York (Eckhardt and others, 2008). In 2007, a study of groundwater quality in tributary basins that drain to Lake Ontario in central New York was completed and is the subject of this report. 


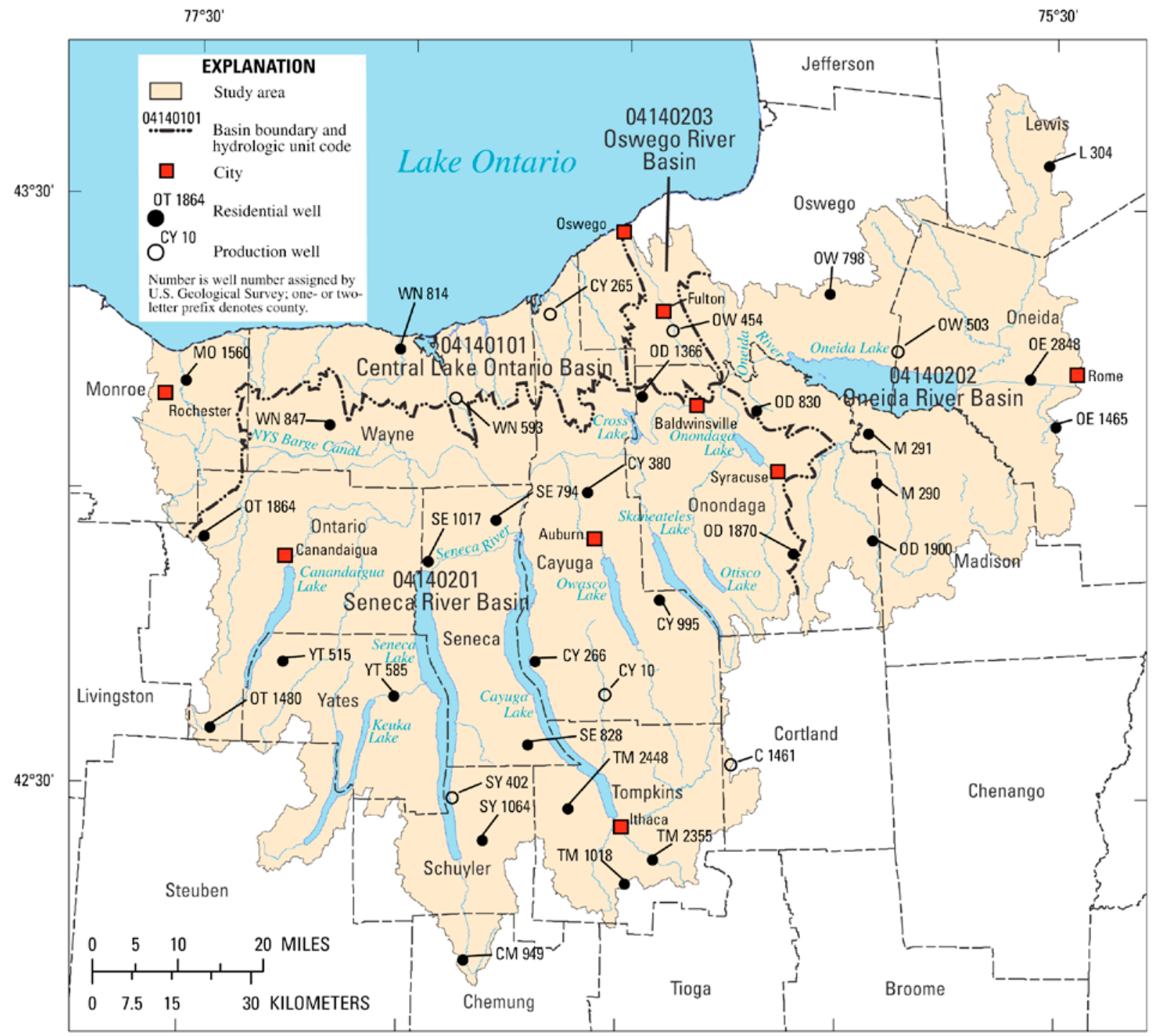

Base from U.S. Geological Survey, Seamless Data Distribution System, accessed in 2008 at http://seamless.usgs.gov
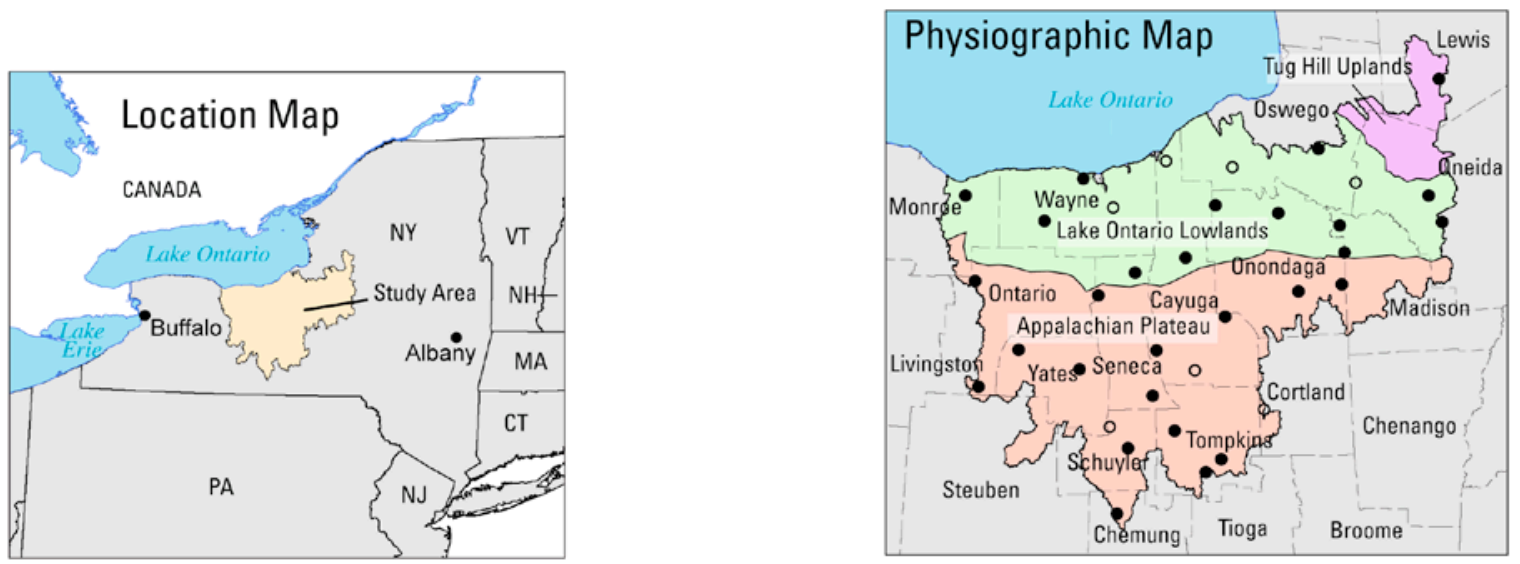

Figure 1. Pertinent geographic features of study area in central New York, and locations of the 35 wells sampled in 2007. (Well data are given in table A1 at end of report.) 


\section{Purpose and Scope}

This report presents the results of the 2007 study of groundwater quality in central New York. It first describes the study area and the sampling methods, then presents results of the water-quality analyses. The area and population is given for each basin (table 1), and the land use, surficial geology, and bedrock geology is illustrated for the study area (figures 2 through 4). Summary statistics (number of samples exceeding Federal or State drinking-water standards) and the minimum, median, and maximum concentrations of all analytes in 35 samples from wells in sand and gravel and bedrock aquifers are given in tables 2-4; detailed analytical results are given in tables A1-A9 (at end of report). Analytical results for selected constituents are compared with Federal and New York State drinking-water standards, which are typically identical. The standards include Maximum Contaminant Levels (MCLs), Secondary Maximum Contaminant Levels (SMCLs), and Health Advisories (HAs) established by the USEPA (2002, 2004, and 2006) and the New York State Department of Health (NYSDOH, 2007b). MCLs specify the highest level of a contaminant that is allowed in drinking water; they are based on human health criteria and are legally enforceable by Federal and State authorities. SMCLs are non-enforceable guidelines based on cosmetic and aesthetic criteria, such as taste and odor. HAs are estimates of acceptable drinking-water levels for contaminants that can affect human health; they are non-enforceable standards that provide technical guidance for water use.

\section{Study Area}

The study area includes all or parts of 18 counties in north-central New York (fig. 1; table 1). It encompasses the central Lake Ontario Basin (between Oswego and Rochester) and the Oswego River Basin, which includes the Seneca River and Oneida River Basins and contains Oneida Lake, Onondaga Lake, and the seven easternmost Finger Lakes.

\section{Physiography, Land Use, and Precipitation}

The central and southern parts of the study area lie within the Appalachian Plateau physiographic province (fig. 1, table A1); the northern part lies in the Lake Ontario Lowlands and the Tug Hill Uplands. Forest and pasture dominate the upland rolling hills and narrow valleys of the southern and eastern parts of the study area. The central region has several deep and wide glacial valleys that drain northward and contain the Finger Lakes. Cultivation of row crops, apples, and grapes is common in the Lake Ontario Lowlands, and row-crop, forage-crop, and dairy farming are concentrated in the fertile soils that overlie carbonate bedrock areas between Buffalo and Albany (fig. 2). The Syracuse and Rochester metropolitan areas lie near the central and northwestern parts of the study area, respectively, and the New York State Barge Canal (formerly known as the Erie Canal) traverses the area from Rochester to Rome and from Syracuse to Oswego (fig. 1).

Land-surface elevations range from about $250 \mathrm{ft}$ at Lake Ontario to about 2,000 ft in the western and southern uplands. The climate is humid, and air temperatures are moderated by Lake Ontario and the Finger Lakes. Virtually all groundwater in the area originates as precipitation, which ranges from about 32 inches per year (in/yr) in the south-central areas to about 52 in/yr in the Tug Hill Upland (fig. 1); mean annual precipitation is about 39 in. About 20 percent of the annual precipitation infiltrates the land surface and recharges the sand and gravel and bedrock aquifers (Randall, 2001). 
Table 1. Basin areas and population of the central New York study area, by drainage basin.

[Basin locations are shown in figure 1. Population: 2000 Census (U.S. Department of Commerce, 2000)]

\begin{tabular}{lccr}
\hline \multicolumn{1}{c}{ Drainage basin } & $\begin{array}{c}\text { Hydrologic } \\
\text { unit code }\end{array}$ & $\begin{array}{c}\text { Area } \\
\text { (square miles) }\end{array}$ & Population \\
\hline Oswego River $^{1}$ & 04140201, 04140202, 041402033 & 5,097 & $1,043,194$ \\
Central Lake Ontario $^{2}$ & 04140101 & 702 & 548,940 \\
\hline
\end{tabular}

${ }^{1}$ Includes the Seneca River and Oneida River basins.

${ }^{2}$ Includes tributary basins to Lake Ontario between the Oswego River and the Genesee River basins.

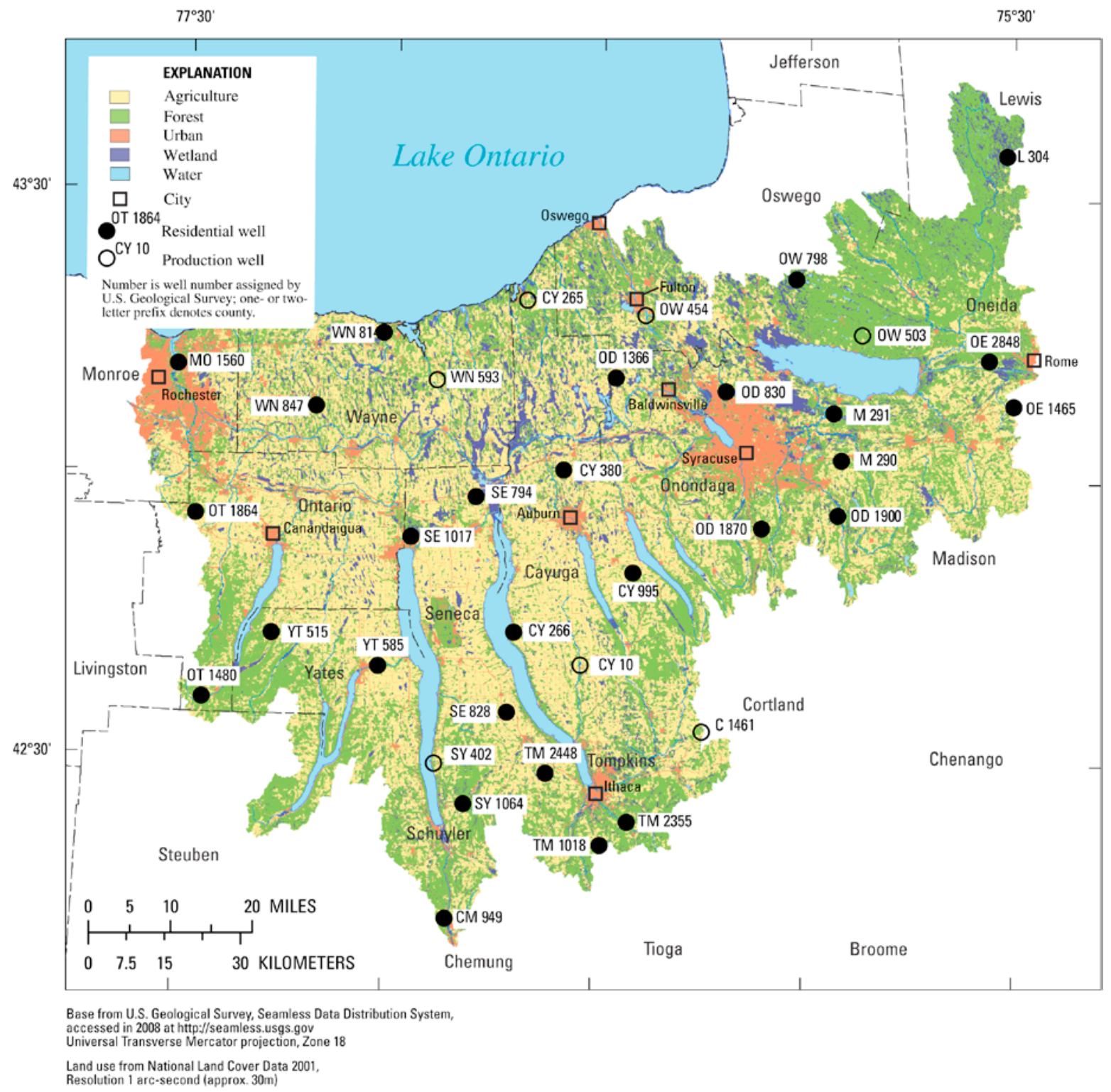

Figure 2. Land use in central New York study area and locations of the 35 wells sampled in 2007. (Well data are given in table A1.) 


\section{Glacial Deposits}

Glacially derived deposits are generally present throughout central New York (fig. 3). Glaciers scoured the hills and valleys of New York and left a thin mantle of till on top of the bedrock in upland areas and morainal deposits of fine-grained, poorly sorted material that formed valley plugs and low ridges (Cadwell and Muller, 1986). During the subsequent period of deglaciation, meltwater streams deposited thick layers of stratified drift (glaciofluvial sand and gravel) in front of the glaciers and on top, beneath, and alongside them to form deposits that are present as outwash plains, eskers, kettles, kames, and kame terraces. In some areas near Lake Ontario, thick sequences of beach sands were deposited along the shores of proglacial lakes. These water-borne deposits of sand and gravel, where saturated with groundwater, now form locally significant aquifers. Glacial meltwaters also deposited fine particles in proglacial lakes, where they settled to form poorly permeable deposits of lacustrine clay, silt, and fine sand. Recent alluvial deposits cover some of the glacial deposits and form floodplains along the larger streams and rivers and on the terraces along the shore of Lake Ontario. The glacial deposits within the study area are described in detail by Fairchild (1928), Coates (1966), Waller and Finch (1982), Miller (1982, 1988, 1990), Randall (2001), and Kontis and others (2004).

\section{Bedrock}

The bedrock aquifers in the study area (fig. 4) consist of relatively flat-lying, interbedded sedimentary units of shale, siltstone, sandstone, limestone, and dolostone of Ordovician, Silurian, and Devonian age (Broughton and others, 1962; Isachsen and others, 2000). Two bands of carbonate-rock aquifers-limestones and dolostones - extend from Rochester to Rome, and from Canandaigua to east of Syracuse; interbedded Silurian shale, dolostone, and evaporites (salt and gypsum) crop out in the area between the carbonate-rock aquifers. 


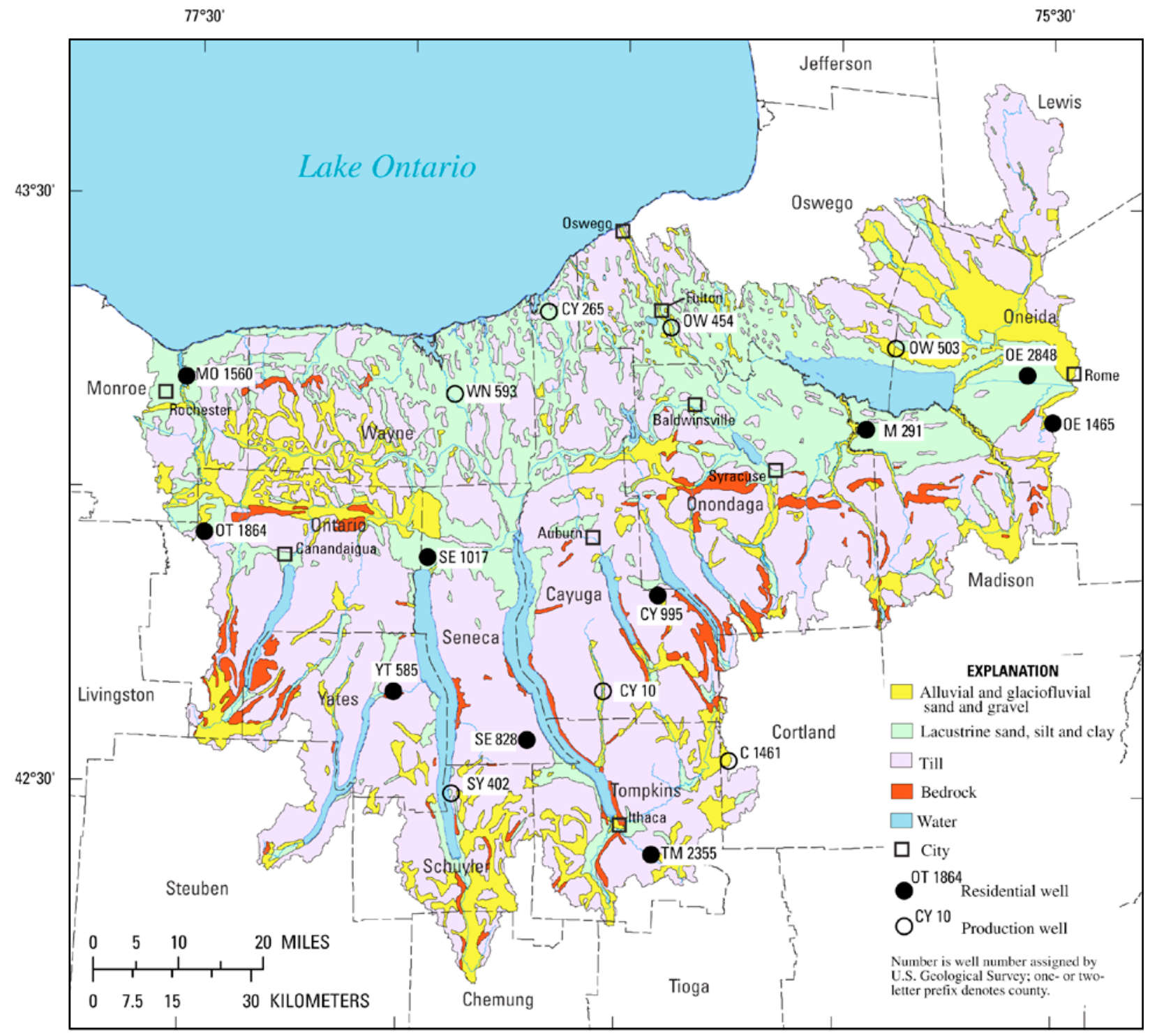

Base from U.S. Geological Survey, Seamless Data Distribution System,

accessed in 2008 at http:/seamless.usgs.gov

Surficial Geology from New York State Museum, 1:250,000

Figure 3. Generalized surficial geology of central New York study area and locations of the 17 wells screened in sand and gravel aquifers that were sampled in 2007. (Well data are given in table A1.) 


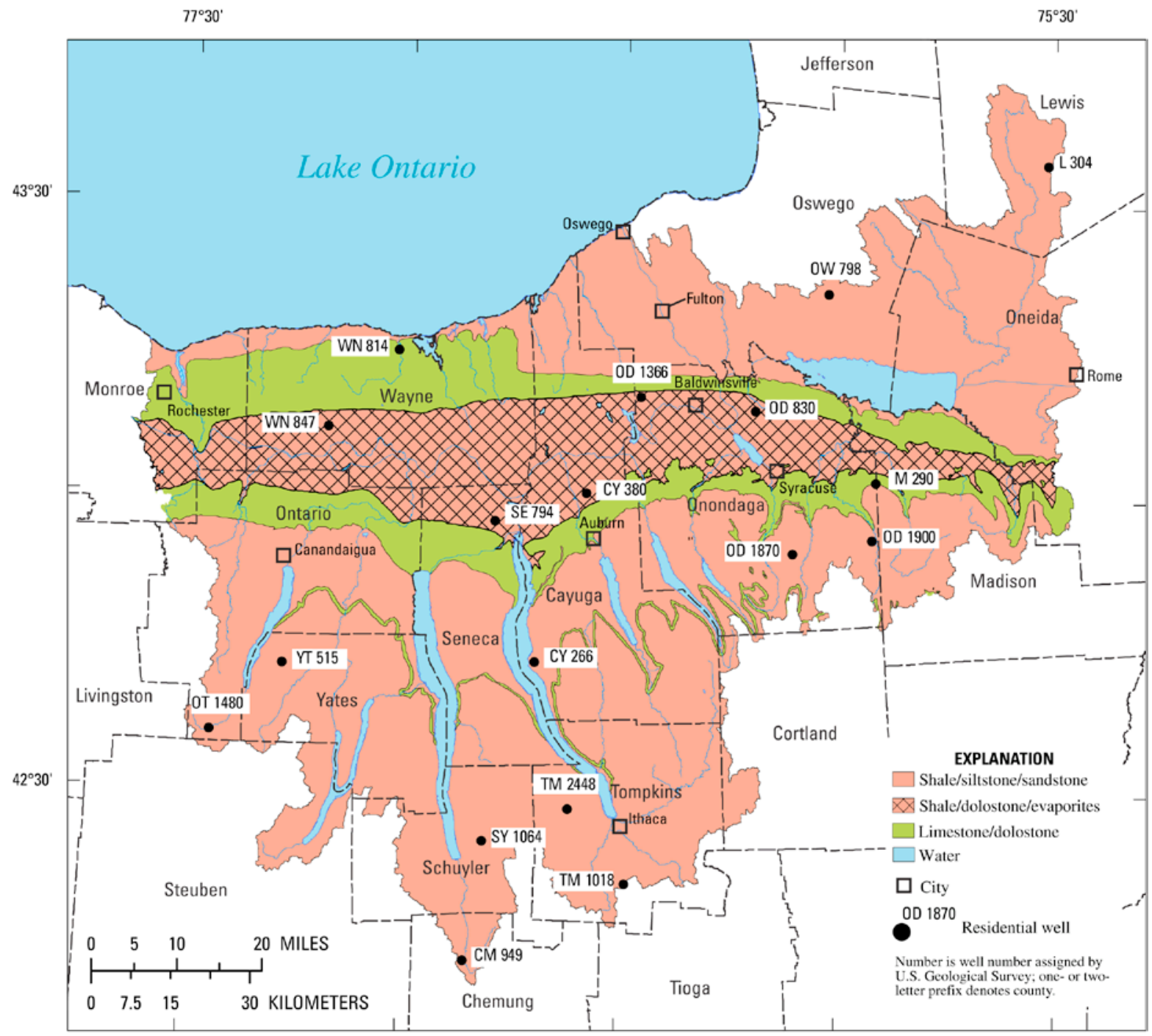

Base from U.S. Geological Survey, Seamless Data Distribution System, accessed in 2008 at hittp://seamless. usgs.gov 18

Bedrock Geology from New York State Museum, 1:250,000

Figure 4. Generalized bedrock geology of central New York study area and locations of the 18 wells completed in bedrock that were sampled in 2007. (Well data are given in table A1.)

\section{Population and Water Supply}

Most of the study area is predominantly rural, but it includes the large cities of Syracuse and Rochester and several small cities such as Auburn, Fulton, Ithaca, Oswego, Rome, and many villages and hamlets (fig. 1). The largest developed, urban areas are Syracuse and Rochester and their suburbs in Onondaga and Monroe Counties (fig. 2). Total population of the study area in 2000 was about 1.6 million, about half of which lives in the Syracuse and Rochester metropolitan areas (U.S. Department of Commerce, 2000). Production wells (wells that provide water for more than 25 people) supply about 35 million gallons per day (Mgal/d) of water for commercial and domestic use within the study area (New York State Department of Health, 2007a). 
The largest water suppliers are the Onondaga County Water Authority, which provides the residents of the Syracuse area with water from Skaneateles and Otisco Lakes and Lake Ontario, and the Monroe County Water Authority, which provides residents in the Rochester area with water from Lake Ontario. Many small cities such as Ithaca and Auburn tap reservoirs and lakes for their water supply, but many rural communities that lie in areas beyond municipal water-supply lines rely on community watersystem (production) wells that tap groundwater from bedrock or from surficial deposits of sand and gravel. Most homeowners that live in rural areas have private wells that tap local surficial deposits or bedrock.

The most productive aquifers within the study area are the glacial and alluvial deposits of sand and gravel (fig. 3). Anderson and others (1982) estimated that sand and gravel aquifers near Fulton can yield as much as 250 gallons per minute (gal/min). Some wells completed in the sand and gravel aquifer adjacent to the Oswego River may induce surface-water infiltration. Wells in the sand and gravel deposits along the Seneca River south and east of Baldwinsville may potentially yield more than $350 \mathrm{gal} / \mathrm{min}$ (Kantrowitz, 1970; Pagano and others, 1986). Till deposits cover much of the upland areas, but they are typically thin, relatively impermeable, and yield little water to wells. Lacustrine fine sand, silt, and clay deposits are present in most large valleys but yield little or no water to wells. The fine-grained beds confine and help protect productive sand and gravel aquifers that lie beneath them. Bedrock aquifers (fig. 4) are used for water supply where sand and gravel aquifers are absent, typically in upland areas. The bedrock aquifers in the study area may yield water of poorer chemical quality than the surficial aquifers; for example, the carbonate rock aquifers typically yield very hard water, and shale bedrock aquifers near Onondaga Lake and Lake Ontario may yield salty water (Kantrowitz, 1970; Crain, 1975; Yager and others, 2007).

\section{Methods}

A total of 35 wells were selected for sample collection-17 are finished in sand and gravel aquifers (fig. 3), and 18 are finished in bedrock aquifers (fig. 4). Of the 17 wells that tap sand and gravel aquifers, 7 are production wells and 10 are private residential wells. All of the 18 bedrock wells are private residential wells. Sampling was done from August through December 2007. The water samples were analyzed for 6 physical properties and 216 constituents, including 4 types of bacteria. Three samples - two field blanks and one replicate sample-were collected for quality assurance (QA) and quality control (QC), as required for the Federal 305(b) program.

\section{Site Selection}

Wells were selected to provide a spatial representation of water use within the study area. The wells were identified through (1) the USGS National Water Information System (NWIS) database, (2) the NYSDEC Water-Well Reporting Program, and (3) information from State and county health departments. The Water-Well Reporting Program was implemented in 2000 to collect information on well construction, geology, and yield for newly drilled wells throughout New York from licensed well drillers; the resulting database provides useful information for groundwater studies. A letter requesting permission to sample the water was sent to owners of residential wells that were identified as potential sampling sites; the letter described the project and included a questionnaire requesting information on the location of the well, the most convenient times for sampling, any safety concerns around the well, and other information.

Production wells were identified through the NYSDOH and by local water managers of villages and cities throughout the study area. The water managers were sent a project description and a questionnaire similar to those sent to residential well owners. Residential and production well owners who responded favorably were contacted by telephone to clarify information about the wells and to arrange sampling dates. 
Most of the wells finished in sand and gravel aquifers (fig. 3) are in valleys, and the well depths ranged from 31 to $145 \mathrm{ft}$ (table A1). All the production wells that tap sand and gravel aquifers have slotted screens, whereas most residential wells that tap sand and gravel simply have an open-ended steel casing. The bedrock wells (fig. 4) are generally in upland terrains, and depths ranged from 33 to $300 \mathrm{ft}$ (table A1); these wells typically have a steel casing set into open boreholes in competent rock, and water yields are obtained by flow through bedrock fractures to the well.

Site selection did not target specific municipality, industrial, or agricultural practices; rather, sampling sites were selected to represent areas of greatest groundwater use and to obtain a geographical representation of the study area and its aquifers (figs. 2-4). Site selection included wells in each of four predominant land-use categories-agriculture, urban, forest, and wetland.

Shallow wells that tap sand and gravel aquifers are susceptible to contamination by several types of compounds, including volatile organic compounds (VOCs), pesticides, deicing chemicals, and nutrients from nearby highways and industrial, agricultural, and residential areas. The movement of these contaminants to the water table through the soils and surficial sand and gravel can be relatively rapid. Bedrock wells that tap sandstone and shale aquifers in rural upland areas are generally less susceptible to contamination from industrial and urban sources, which are mainly in the valleys; but bedrock wells in lowland areas underlain by carbonate rock (limestone and dolostone) may be vulnerable to contamination from surface runoff because infiltration rates and groundwater flow can be relatively rapid through solution features in the rock. Agricultural land that surrounds wells may be a potential source of contamination from fertilizers, pesticides, and fecal waste from livestock; lawns and residential septic systems also are a potential source of these contaminants. In addition to contaminants from human activities, the aquifers contain naturally derived elements that may diminish water quality, such as sodium, chloride, sulfate, iron, manganese, and trace elements such as arsenic; some aquifers may contain hydrogen sulfide, methane, and radon gases from deep-lying sources.

\section{Sampling Methods}

Water samples were analyzed for the physical properties and constituents listed in Appendix tables A2-A9 (at end of report). The categories are as follows: physical properties (table A3), inorganic constituents (table A4), nutrients and total organic carbon (table A5), trace elements and radon-222 (table A6), pesticides (table A7), VOCs (table A8), bacterial water-quality indicators (table A9), and phenols (none detected, table A2). Samples were collected from every well for these analyses and were processed by methods described in USGS manuals for the collection of water-quality data (U.S. Geological Survey, variously dated). Samples collected for pesticide analyses were processed by the methods of Shelton (1994), Sandstrom and others (2001), and Wilde and others (2004). These samples were analyzed at the USGS National Water Quality Laboratory (NWQL) and the USGS Kansas Organic Geochemistry Research Laboratory (OGRL) for 132 pesticides and pesticide degradates through methods described by Zaugg and others (1995), Furlong and others (2001), Sandstrom and others (2001), Meyer and others (1993), and Lee and Strahan (2003). The analytical method devised by Zaugg and others (1995) was developed in cooperation with the USEPA and allows detection of the Nation's most commonly used pesticides. Samples for bacterial analyses were processed in accordance with NYSDOH guidelines.

Sampling was done at all sites in the following steps. The well pump was turned on (many of the production wells were already running) and allowed to run until at least five casing volumes of well water had passed the sampling point. A raw-water tap between the well and the pressure tank was opened, and the water was allowed to flush for several minutes. During this time, a visual evaluation of the area surrounding the well was conducted to identify potential sources of contamination that could affect the well water. Samples were collected from the raw-water tap to avoid all water-treatment systems and to ensure that the water collected was representative of the aquifer. A Teflon ${ }^{\circledR}$ discharge line was then connected to the tap, and samples were analyzed with a multiprobe meter for physical properties 
(temperature, specific conductance, dissolved-oxygen concentration, and $\mathrm{pH}$ ). After the measurements of these properties had stabilized, a second Teflon ${ }^{\circledR}$ discharge line was connected to the first with a stainlesssteel quick-connect fitting and was directed into a sample-collection chamber mounted on a plastic box; this chamber was used to minimize sample exposure to dust and other potential sources of contamination. Bottles were filled within the chamber according to standard USGS field methods (U.S. Geological Survey, 2007).

The analyses for physical properties, most trace elements and metals, acid-neutralizing capacity, organic carbon, radon-222, VOCs, and phenols were done on unfiltered water samples to obtain total whole-water concentrations. Dissolved concentrations of nutrients, major inorganic constituents, three metals, and pesticides were obtained from filtered samples. Concentrations of iron and manganese in unfiltered samples were compared with those in filtered samples to obtain the difference between the total and dissolved concentrations (table A6). To prevent sample degradation, sulfuric acid was added to the samples collected for phenol analysis, hydrochloric acid was added to samples collected for total organic carbon and VOC analyses, and nitric acid was added to some of the samples collected for trace-element analyses. Samples collected for analysis of dissolved inorganic compounds were filtered through a 0.45-micrometer $(\mu \mathrm{m})$ cellulose capsule filter that was attached to the Teflon ${ }^{\circledR}$ discharge line inside the sample-collection chamber; samples for analysis of pesticides were filtered through a 0.7- $\mu$ m furnacebaked glass-fiber plate filter using the methods of Wilde and others (2004).

All Teflon ${ }^{\circledR}$ discharge lines were cleaned in the laboratory before each sampling day and in the field between each sample collection. New sample-chamber bags were used at each sampling site. Samples for radon analysis were obtained through an in-line septum chamber with a disposable syringe to avoid atmospheric contamination. Samples for bacterial analysis were collected in sterile containers provided by the bacteriological laboratory; the connection of the sampling tube to the well tap was not sterilized.

The samples were stored on ice in coolers and delivered directly, or shipped by overnight delivery, to the following four laboratories: (1) the USGS NWQL in Denver, Colorado, for analysis for inorganic major ions, nutrients, inorganic trace elements and radon-222, some pesticides, and VOCs; (2) the USGS OGRL in Lawrence, Kansas, for other pesticides; (3) a New York State-certified private laboratory in Melville, NY, for total organic carbon and phenolic compounds; and (4) a laboratory in Ithaca, NY, approved by New York State for bacterial analysis.

\section{Groundwater Quality}

The 35 groundwater samples collected during this study were analyzed for 6 physical properties and 216 constituents, including 4 types of bacteria. Most (137) of the chemical constituents were not detected in any sample (table A2). The results of the physical-property measurements are listed in table A3. The concentrations of the 75 detected chemical constituents are listed in tables A4-A8, and the results

for 4 types of bacteria are listed in table A9. The quality of the sampled groundwater was generally within NYSDOH and USEPA guidelines, although in some samples the concentrations of certain constituents exceeded recommended MCLs, SMCLs, or HAs set by the USEPA (2006) and the NYSDOH (2007b). In general, most of the water-quality problems involve taste or odor and excessive hardness, iron, or manganese that develop from natural interactions of water and rock minerals in the subsurface. 
The QA/QC field blanks contained no constituent in concentrations greater than the laboratory reporting levels, except toluene, which was detected in one blank sample at a trace concentration of $0.1 \mu \mathrm{g} / \mathrm{L}$; this indicates that little to no contamination occurred through the sampling or analytical procedures. The results of analysis of the two QA/QC replicate samples indicate that variability in sample results meet the precision requirements of the study. The analytes with the largest percent differences between concentration in a groundwater sample and that in the replicate sample were acid-neutralizing capacity, residue on evaporation, and low-concentration trace elements (concentrations near the laboratory reporting level for the elements).

\section{Physical Properties}

The $\mathrm{pH}$ of the samples (table A3) ranged from 6.8 to 8.3, and none of the 35 samples was outside the accepted SMCL range of 6.5 to 8.5 (U.S. Environmental Protection Agency, 2006). Specific conductance of the samples ranged from 141 to $11,700 \mu \mathrm{S} / \mathrm{cm}$. Dissolved oxygen concentrations ranged from less than $0.3 \mathrm{mg} / \mathrm{L}$ (the analytical detection limit) at 10 wells to $9.1 \mathrm{mg} / \mathrm{L}$ at one well. One sample had a water color that exceeded the Federal SMCL and the New York State MCL of 15 platinum-cobalt units. The odor of hydrogen sulfide gas, which may occur in the absence of oxygen, was noted by field personnel in water from 8 of the 35 wells.

\section{Inorganic Major lons}

Water from the wells was generally a calcium-bicarbonate type, although water from two wells [MO 1560 and TM 1018] (fig. 1) was a sodium-bicarbonate type. Water from two wells [OE 1465 and YT 515] was a sodium-chloride type, and water from one well [SE 794] was a calcium-sulfate type (Hem, 1985). The cations that were detected in the highest concentrations were calcium, magnesium, and sodium (tables 2 and A4). Calcium concentrations ranged from 15.0 to $489 \mathrm{mg} / \mathrm{L}$, and magnesium concentrations ranged from 5.46 to $115 \mathrm{mg} / \mathrm{L}$. Calcium and magnesium contribute to water hardness, and 22 of the 35 wells yielded water with hardness greater than $180 \mathrm{mg} / \mathrm{L}$, which is classified as "very hard" (Hem, 1985). The median hardness is $260 \mathrm{mg} / \mathrm{L}$ for samples from sand and gravel wells and $175 \mathrm{mg} / \mathrm{L}$ for samples from bedrock wells. Sodium concentrations ranged from 1.20 to 1,870 mg/L, and the USEPA Health Advisory (HA), which recommends that sodium concentrations in drinking water not exceed $60 \mathrm{mg} / \mathrm{L}$ to minimize the taste, was exceeded in eight samples. This HA for sodium is not federally enforceable but is intended as a guideline for consumers (U.S. Environmental Protection Agency, 2002, 2006).

The anions that were detected in the highest concentrations were bicarbonate (alkalinity), chloride, and sulfate (tables 2 and A4). Bicarbonate concentrations ranged from 78 to $742 \mathrm{mg} / \mathrm{L}$ (as $\mathrm{CaCO}_{3}$ ). Chloride concentrations ranged from 0.68 to $3,380 \mathrm{mg} / \mathrm{L}$; the Federal SMCL and the New York State MCL of $250 \mathrm{mg} / \mathrm{L}$ for chloride was exceeded in two samples. Sulfate concentrations ranged from less than $0.18 \mathrm{mg} / \mathrm{L}$ (the analytical detection limit) to $543 \mathrm{mg} / \mathrm{L}$; the Federal SMCL and the New York State MCL of $250 \mathrm{mg} / \mathrm{L}$ for sulfate was exceeded in two samples. 
Table 2. Summary statistics for concentrations of major ions in sand and gravel aquifers and bedrock aquifers in central New York, 2007.

[Concentrations are in milligrams per liter (mg/L). All samples represent filtered water; -, not applicable; $<$, less than; E, estimated]

\begin{tabular}{|c|c|c|c|c|c|c|c|c|c|}
\hline \multirow{2}{*}{\multicolumn{2}{|c|}{ Constituent }} & \multirow{2}{*}{$\begin{array}{l}\text { Drinking- } \\
\text { water } \\
\text { standard }\end{array}$} & \multirow{2}{*}{$\begin{array}{l}\text { Number of } \\
\text { samples } \\
\text { exceeding } \\
\text { standard }\end{array}$} & \multicolumn{3}{|c|}{$\begin{array}{c}\text { Sand and gravel } \\
\text { (17 samples) }\end{array}$} & \multicolumn{3}{|c|}{$\begin{array}{c}\text { Bedrock } \\
\text { (18 samples) }\end{array}$} \\
\hline & & & & $\begin{array}{l}\text { Mini- } \\
\text { mum }\end{array}$ & Median & $\begin{array}{l}\text { Maxi- } \\
\text { mum }\end{array}$ & $\begin{array}{l}\text { Mini- } \\
\text { mum }\end{array}$ & Median & $\begin{array}{l}\text { Maxi- } \\
\text { mum }\end{array}$ \\
\hline \multirow{4}{*}{$\begin{array}{l}\frac{n}{c} \\
\stackrel{0}{+0} \\
\text { U }\end{array}$} & Calcium & - & - & 18.2 & 73.1 & 132 & 15.0 & 50.6 & 489 \\
\hline & Magnesium & - & - & 5.46 & 22.3 & 47.8 & 7.64 & 14.4 & 115 \\
\hline & Potassium & - & - & .41 & 1.31 & 5.62 & .65 & 1.97 & 37.7 \\
\hline & Sodium & ${ }^{1} 60$ & 8 & 1.20 & 14.2 & 343 & 2.14 & 24.2 & 1,870 \\
\hline \multirow{4}{*}{$\frac{n}{\frac{0}{2}}$} & Bicarbonate & - & - & 78 & 322 & 445 & 101 & 250 & 742 \\
\hline & Chloride & ${ }^{2,3} 250$ & 2 & 1.49 & 26.7 & 663 & .68 & 16.6 & 3,380 \\
\hline & Fluoride & ${ }^{2} 2.2,{ }^{3} 2.0$ & 0 & $<.12$ & .11 & .42 & Е .07 & .19 & .92 \\
\hline & Sulfate & ${ }^{2,3} 250$ & 2 & $<.18$ & 26.1 & 139 & E.14 & 26.9 & 543 \\
\hline \multicolumn{4}{|c|}{ Hardness, $\mathrm{mg} / \mathrm{L}$ as $\mathrm{CaCO}_{3}$} & 68 & 260 & 490 & 84 & 175 & 1,700 \\
\hline \multicolumn{4}{|c|}{ Alkalinity, $\mathrm{mg} / \mathrm{L}$ as $\mathrm{CaCO}_{3}$} & 64 & 263 & 365 & 83 & 211 & 608 \\
\hline \multicolumn{4}{|c|}{ Residue on evaporation, mg/L } & 74 & 348 & 1,400 & 98 & 328 & 7,130 \\
\hline
\end{tabular}

\section{Nutrients and Organic Carbon}

Nitrate and ammonia were the predominant nutrients in the groundwater samples (tables 3 and A5); nitrite and organic nitrogen concentrations were negligible in most samples. Nitrate plus nitrite concentrations ranged from less than 0.04 (the analytical detection limit) to $7.34 \mathrm{mg} / \mathrm{L}$ as nitrogen (N); the median concentration was $0.25 \mathrm{mg} / \mathrm{L}$ in samples from sand and gravel wells and $0.07 \mathrm{mg} / \mathrm{L}$ in samples from bedrock wells. The nitrate MCL of $10 \mathrm{mg} / \mathrm{L}$ (as $\mathrm{N}$ ) was not exceeded in any sample, and the concentrations in 17 of the 35 samples were below the detection limit. Ammonia concentrations ranged from less than 0.02 to $4.33 \mathrm{mg} / \mathrm{L}$ as $\mathrm{N}$. Orthophosphate was detected in 34 of the 35 samples, but concentrations were low; the maximum concentration was $0.047 \mathrm{mg} / \mathrm{L}$ (as phosphorus). Total organic carbon was detected in 16 of the 35 samples; concentrations ranged from less than $1.0 \mathrm{mg} / \mathrm{L}$ (the analytical detection limit) to $2.7 \mathrm{mg} / \mathrm{L}$. 
Table 3. Summary statistics for concentrations of nutrients and organic carbon in sand and gravel aquifers and bedrock aquifers in central New York, 2007.

[All samples represent filtered water except as noted; mg/L, milligrams per liter; -, not applicable; <, less than; E, estimated; N, nitrogen; $\mathrm{P}$, phosphorus]

\begin{tabular}{|c|c|c|c|c|c|c|c|c|}
\hline \multirow{2}{*}{ Constituent } & \multirow{2}{*}{$\begin{array}{l}\text { Drinking- } \\
\text { water } \\
\text { standard }\end{array}$} & \multirow{2}{*}{$\begin{array}{l}\text { Number of } \\
\text { samples } \\
\text { exceeding } \\
\text { standard }\end{array}$} & \multicolumn{3}{|c|}{$\begin{array}{l}\text { Sand and gravel } \\
\text { (17 samples) }\end{array}$} & \multicolumn{3}{|c|}{$\begin{array}{l}\text { Bedrock } \\
\text { (18 samples) }\end{array}$} \\
\hline & & & $\begin{array}{l}\text { Mini- } \\
\text { mum }\end{array}$ & Median & $\begin{array}{l}\text { Maxi- } \\
\text { mum }\end{array}$ & $\begin{array}{l}\text { Mini- } \\
\text { mum }\end{array}$ & Median & $\begin{array}{l}\text { Maxi- } \\
\text { mum }\end{array}$ \\
\hline $\begin{array}{l}\text { Ammonia plus } \\
\text { organic } \mathrm{N}, \mathrm{mg} / \mathrm{L} \text { as } \mathrm{N}\end{array}$ & - & - & $<0.10$ & Е 0.06 & 0.37 & $<0.10$ & 0.17 & 4.5 \\
\hline Ammonia, $\mathrm{mg} / \mathrm{L}$ as $\mathrm{N}$ & - & - & $<0.020$ & Е .020 & .335 & $<0.020$ & .110 & 4.33 \\
\hline $\begin{array}{l}\text { Nitrate plus nitrite, } \\
\mathrm{mg} / \mathrm{L} \text { as } \mathrm{N}\end{array}$ & 1,210 & 0 & $<.04$ & .25 & 7.34 & $<.04$ & .07 & 5.35 \\
\hline Nitrite, $\mathrm{mg} / \mathrm{L}$ as $\mathrm{N}$ & ${ }^{1,2} 1$ & 0 & $<.002$ & $<.002$ & .089 & $<.002$ & $<.002$ & .039 \\
\hline $\begin{array}{l}\text { Orthophosphate, } \\
\mathrm{mg} / \mathrm{L} \text { as } \mathrm{P}\end{array}$ & - & - & E.003 & E.005 & .031 & $<.006$ & E.005 & .047 \\
\hline $\begin{array}{l}\text { Total organic carbon, } \\
\text { unfiltered, } \mathrm{mg} / \mathrm{L}\end{array}$ & - & - & $<1.0$ & 1.1 & 2.4 & $<1.0$ & $<1.0$ & 2.7 \\
\hline
\end{tabular}

${ }^{1}$ USEPA Maximum Contaminant Level.

${ }^{2}$ NYSDOH Maximum Contaminant Level.

\section{Trace Elements and Radon-222}

The trace elements most commonly detected in the 35 samples were barium, boron, lithium, and strontium, all of which were detected in every sample (tables 4 and A6). The elements detected in the highest concentrations were barium, boron, iron, lithium, manganese, and strontium. Barium concentrations ranged from 10.5 to $10,400 \mu \mathrm{g} / \mathrm{L}$, and the MCL for barium $(2,000 \mu \mathrm{g} / \mathrm{L})$ was exceeded once. Boron concentrations ranged from 5.0 to 3,140 $\mu \mathrm{g} / \mathrm{L}$; MCLs have not been established for boron. Iron was detected in 26 of the 35 filtered samples at concentrations ranging from 4 to 3,530 $\mu \mathrm{g} / \mathrm{L}$ (table A6); the Federal SMCL and the New York State MCL for iron $(300 \mu \mathrm{g} / \mathrm{L})$ was exceeded in 10 samples. Lithium concentrations ranged from 1.3 to 1,900 $\mu \mathrm{g} / \mathrm{L}$; MCLs have not been established for lithium. Manganese was detected in 31 of the 35 filtered samples at concentrations ranging from $0.2 \mu \mathrm{g} / \mathrm{L}$ to 515 $\mu \mathrm{g} / \mathrm{L}$; the Federal SMCL for manganese $(50 \mu \mathrm{g} / \mathrm{L})$ was exceeded in 10 filtered samples, and the New York State MCL (300 $\mu \mathrm{g} / \mathrm{L})$ was exceeded in one filtered sample. Strontium concentrations ranged from 32.9 to $53,800 \mu \mathrm{g} / \mathrm{L}$, but MCLs have not been established for strontium.

Aluminum was detected in 24 of the 35 samples, and the SMCL (50 $\mu \mathrm{g} / \mathrm{L})$ was exceeded in samples from three wells. Arsenic was detected in 24 samples, but the MCL $(10 \mu \mathrm{g} / \mathrm{L})$ was not exceeded. Lead was detected in 34 samples, but the MCL $(15 \mu \mathrm{g} / \mathrm{L})$ was not exceeded.

Uranium was detected in 30 samples, but none exceeded the MCL of $30 \mu \mathrm{g} / \mathrm{L}$. The MCLs for antimony (6 $\mu \mathrm{g} / \mathrm{L})$, beryllium (4 $\mu \mathrm{g} / \mathrm{L})$, cadmium (5 $\mu \mathrm{g} / \mathrm{L})$, chromium $(100 \mu \mathrm{g} / \mathrm{L})$, selenium $(50 \mu \mathrm{g} / \mathrm{L})$, and silver $(100 \mu \mathrm{g} / \mathrm{L})$ and the SMCLs for copper $(1,000 \mu \mathrm{g} / \mathrm{L})$ and zinc $(5,000 \mu \mathrm{g} / \mathrm{L})$ were not exceeded in any sample. Mercury was not detected in any sample (table A2).

Radon-222 was detected in every sample (table A6), and concentrations ranged from 70 to $1,000 \mathrm{pCi} / \mathrm{L}$. The median concentration was $170 \mathrm{pCi} / \mathrm{L}$ in samples from sand and gravel wells and 215 
pCi/L in samples from bedrock wells. The proposed MCL of $300 \mathrm{pCi} / \mathrm{L}$ for radon-222 in drinking water was exceeded in 12 samples, but the proposed Alternate Maximum Contaminant Level AMCL of 4,000 pCi/L was not exceeded. The AMCL is the proposed allowable concentration of radon in raw-water samples where the State has implemented mitigation programs to address the health risks of radon in indoor air. The proposed MCL and AMCL for radon are under review and have not been adopted (U.S. Environmental Protection Agency, 2004, 2006).

Table 4. Summary statistics for concentrations of trace elements and radon-222 in sand and gravel aquifers and bedrock aquifers in central New York, 2007.

[All concentrations are in micrograms per liter $(\mu \mathrm{g} / \mathrm{L})$ except as noted. All samples unfiltered except as noted. pCi/L, picocuries per liter; -, not applicable; E, estimated; <, less than]

\begin{tabular}{|c|c|c|c|c|c|c|c|c|}
\hline \multirow{2}{*}{ Constituent } & \multirow{2}{*}{$\begin{array}{l}\text { Drinking- } \\
\text { water } \\
\text { standard }\end{array}$} & \multirow{2}{*}{$\begin{array}{l}\text { Number of } \\
\text { samples } \\
\text { exceeding } \\
\text { standard }\end{array}$} & \multicolumn{3}{|c|}{$\begin{array}{l}\text { Sand and gravel } \\
\text { (17 samples) }\end{array}$} & \multicolumn{3}{|c|}{$\begin{array}{l}\text { Bedrock } \\
\text { (18 samples) }\end{array}$} \\
\hline & & & $\begin{array}{l}\text { Mini- } \\
\text { mum }\end{array}$ & Median & $\begin{array}{l}\text { Maxi- } \\
\text { mum }\end{array}$ & $\begin{array}{l}\text { Mini- } \\
\text { mum }\end{array}$ & Median & $\begin{array}{l}\text { Maxi- } \\
\text { mum }\end{array}$ \\
\hline Aluminum & ${ }^{3} 50$ & 3 & $<2$ & E 2 & 41 & $<4$ & 9 & 4,830 \\
\hline Antimony & ${ }^{1,2} 6$ & 0 & $<.1$ & $<.2$ & .2 & $<.1$ & $<.2$ & .5 \\
\hline Arsenic & ${ }^{1} 10$ & 0 & $<.60$ & E.12 & 7.2 & $<.60$ & .39 & 8.7 \\
\hline Barium & ${ }^{1,2} 2,000$ & 1 & 10.5 & 66.7 & 630 & 12.3 & 108 & 10,400 \\
\hline Beryllium & ${ }^{1,2} 4$ & 0 & $<.04$ & $<.06$ & $<.08$ & $<.04$ & $<.04$ & .20 \\
\hline Boron, filtered & - & - & 6.0 & 21 & 111 & 5.0 & 113 & 3,140 \\
\hline Cadmium & 1,25 & 0 & $<.01$ & $<0.02$ & .06 & $<.01$ & $<0.02$ & .02 \\
\hline Chromium & ${ }^{1,2} 100$ & 0 & $<.04$ & $<.60$ & E.48 & $<.40$ & $<.60$ & 44.4 \\
\hline Cobalt & - & - & $<.04$ & E.02 & .17 & $<.04$ & .04 & 4.70 \\
\hline Copper & ${ }^{3} 1,000$ & 0 & $<1.2$ & 1.3 & 14 & $<1.2$ & 1.6 & 180 \\
\hline Iron, filtered & ${ }^{2,3} 300$ & 10 & $<8$ & 49 & 1,930 & $<6$ & 41 & 3,530 \\
\hline Iron & ${ }^{2,3} 300$ & 14 & $<6$ & 158 & 2,860 & $<6$ & 174 & 9,190 \\
\hline Lead & ${ }^{4} 15$ & 0 & .06 & .27 & 2.11 & $<.03$ & .33 & 4.00 \\
\hline Lithium & - & - & 1.3 & 5.1 & 42.7 & 2.7 & 22.9 & 1,900 \\
\hline Manganese, filtered & ${ }^{3} 50-{ }^{2} 300$ & $10-1$ & $<.4$ & 29.1 & 176 & .3 & 8.5 & 515 \\
\hline Manganese & ${ }^{3} 50-{ }^{2} 300$ & $12-2$ & $<.4$ & 32.9 & 178 & 1.1 & 18.0 & 594 \\
\hline Molybdenum & - & - & $<.1$ & .5 & 3.5 & .1 & .5 & 6.0 \\
\hline Nickel & - & - & $<.12$ & .18 & 1.5 & $<.12$ & .30 & 25.4 \\
\hline Selenium & ${ }^{1,2} 50$ & 0 & $<.08$ & $<.08$ & .21 & $<.08$ & $<.08$ & 5.9 \\
\hline Silver & ${ }^{1,2} 100$ & 0 & $<0.02$ & $<0.02$ & $<.04$ & $<0.02$ & $<0.02$ & .06 \\
\hline Strontium & - & - & 32.9 & 180 & 1,100 & 46.5 & 1,545 & 53,800 \\
\hline Thallium & - & - & $<.08$ & $<.18$ & E.05 & $<.08$ & $<.08$ & $<.40$ \\
\hline Uranium & ${ }^{1} 30$ & 0 & $<.012$ & .297 & 2.36 & $<.012$ & .206 & 28.3 \\
\hline Zinc & $2,35,000$ & 0 & $<2.0$ & 2.9 & 23.1 & $<2.0$ & 5.8 & 74.9 \\
\hline Radon-222, pCi/L & ${ }^{5} 300$ & 12 & 70 & 170 & 680 & 70 & 215 & 1,000 \\
\hline \multicolumn{9}{|c|}{${ }^{1}$ USEPA Maximum Contaminant Level. } \\
\hline \multicolumn{9}{|c|}{${ }^{2}$ NYSDOH Maximum Contaminant Level. } \\
\hline \multicolumn{9}{|c|}{${ }^{3}$ USEPA Secondary Maximum Contaminant Level. } \\
\hline \multicolumn{9}{|c|}{${ }^{4}$ USEPA Treatment Technique. } \\
\hline${ }^{5}$ USEPA Proposed & mum Cont & $\mathrm{T}$ & & & & & & \\
\hline
\end{tabular}




\section{Pesticides}

Fifteen pesticides (including 7 pesticide degradates) were detected in water from 17 of the 35 wells (table A7), but none of the concentrations exceeded MCLs. Ten of the samples containing pesticides were from sand and gravel aquifers, and seven were from bedrock aquifers. Caffeine, which is not a pesticide, is measured as part of the pesticide analyses and can be an indicator of human wastes, but it was not detected in any sample (table A2). The pesticide compounds that were detected most frequently were herbicide degradation products-CIAT (2-chloro-4-isopropylamino-6-amino-s-triazine, also called deethylatrazine, a degradation product of atrazine and propazine), alachlor ESA (a degradation product of alachlor), and metolachlor ESA and OA (degradation products of metolachlor). CIAT was detected in nine samples, alachlor ESA in seven samples, and metolachlor ESA and OA in four samples each. The maximum concentration of any herbicide degradation product was $1.51 \mu \mathrm{g} / \mathrm{L}$ (metolachlor ESA). Metolachlor was detected once $(0.006 \mu \mathrm{g} / \mathrm{L})$. Atrazine was detected in six samples; the maximum concentration was $0.088 \mu \mathrm{g} / \mathrm{L}$. Alachlor was not detected (table A2), but its degradation products (alachlor ESA and alachlor ESA 2d amide) were present in eight samples. No Federal MCLs currently have been established for pesticide degradation products, and no pesticide concentration exceeded Federal or New York State MCLs. These trace-level detections of pesticides are similar to those reported by Eckhardt and others (2001), Phillips and others (1999), and Eckhardt and Stackelberg (1995) from studies of pesticides in groundwater throughout New York State.

\section{Volatile Organic Compounds and Phenolic Compounds}

Sixteen VOCs were detected in 15 samples (table A8); the concentration of one compound (trichloroethene) in a sample from one private residential well (50.8 $\mu \mathrm{g} / \mathrm{L}$ at SE 794) exceeded the MCL of $5 \mu \mathrm{g} / \mathrm{L}$. Phenolic compounds, which are semivolatile, were not detected in any sample (table A2). Toluene was detected in nine samples; the maximum concentration was $1.0 \mu \mathrm{g} / \mathrm{L}$. Trichloromethane (chloroform) was detected in five samples, bromodichloromethane and dibromochloromethane were each detected in three samples, and tribromomethane was detected in one sample; these four compounds are called trihalomethanes and are typically formed as by-products when chlorine or bromine are used to disinfect water. New disinfection by-product regulations for primary (production well) water sources have been established (U.S. Environmental Protection Agency, 1998). The regulations specify a MCL goal of zero for bromodichloromethane. Of the three samples in which bromodichloromethane were detected, only one was from a production well (CY 10). Xylene compounds were detected in one sample; the maximum concentration was $1.4 \mu \mathrm{g} / \mathrm{L}$ for the meta plus para isomers. Methyl tert-butyl ether (MTBE), a gasoline additive that can infiltrate into groundwater from leaking fuel tanks, was not detected in any sample (table A2).

\section{Bacteria}

All samples were analyzed for total coliform, fecal coliform, Escherichia coli (E. coli), and heterotrophic bacteria. Total coliform was detected in 19 samples, and fecal coliform was detected once. E. coli was not detected (table A9). The coliform bacteria were detected in 6 samples from sand and gravel aquifers and in 13 samples from bedrock aquifers; 18 of the samples were from private residential wells, and one was from a production well (WN 593; fig. 1), which taps a sand and gravel aquifer. The presence of these bacteria is considered a potential violation of New York State health regulations and would require confirmation of the bacterial detection in additional samples, which was beyond the scope of this study. Accordingly, well owners were notified of positive results upon receipt of laboratory results. The 
raw-water samples collected in this study were collected prior to disinfection treatments, and production wells that provide water supply have chlorination systems that eliminate potential contamination by bacteria before the water is distributed to consumers. However, private residential wells typically lack a chlorination system.

Heterotrophic plate counts (HPCs) ranged from less than 1 (absent) to 6,880 colony-forming units per milliliter (CFU/mL; table A9). The USEPA MCL for HPC is $500 \mathrm{CFU} / \mathrm{mL}$, and three samples exceeded this limit.

\section{Summary}

In 2001, the USGS, in cooperation with the NYSDEC and the USEPA, began an assessment of groundwater quality in bedrock and sand and gravel aquifers throughout New York State. As a part of the assessment in central New York, water samples were collected from 7 production wells and 28 private residential wells from August through December 2007 and were analyzed for 6 physical properties and 216 constituents that include inorganic major ions, nutrients, total organic carbon, trace elements, radon222, VOCs, phenolic compounds, pesticides, and bacteria. The quality of the sampled groundwater was generally acceptable, although in samples from 30 wells the concentrations of at least one constituent exceeded recommended MCLs, SMCLs, or HAs set by the USEPA and the NYSDOH. Of the 75 chemical constituents that were detected, 9 exceeded Federal and State MCLs, SMCLs, or HAs at specific wells, and 3 types of bacteria were detected in concentrations that exceeded MCLs at some wells.

The cations that were detected in the highest concentrations are calcium, magnesium, and sodium; the anions that are detected in the highest concentrations were bicarbonate, chloride, and sulfate. The predominant nutrients were nitrate and ammonia; no sample exceeded the MCL $(10 \mathrm{mg} / \mathrm{L}$ as $\mathrm{N})$ for nitrate. The Health Advisory for sodium in drinking water $(60 \mathrm{mg} / \mathrm{L})$ was exceeded in eight of the 35 samples. The Federal SMCL and the State MCL for sulfate $(250 \mathrm{mg} / \mathrm{L})$ were exceeded in two samples; and the Federal SMCL and State MCL for chloride (250 mg/L) were exceeded in two samples. The water color of one sample exceeded the Federal SMCL and the State MCL (10 color units).

The trace elements detected in the highest concentrations were barium, boron, iron, lithium, manganese, and strontium; for all trace elements, only barium, iron, manganese, and aluminum concentrations exceeded SMCLs. Barium was detected in all 35 samples, and the MCL $(2,000 \mu \mathrm{g} / \mathrm{L}) \mathrm{was}$ exceeded once. Iron was detected in 26 of the 35 filtered samples, and the Federal SMCL and State MCL for iron $(300 \mu \mathrm{g} / \mathrm{L})$ was exceeded in 10 samples. Manganese was detected in 31 filtered samples. The USEPA SMCL $(50 \mu \mathrm{g} / \mathrm{L})$ was exceeded in 10 filtered samples, and the State MCL $(300 \mu \mathrm{g} / \mathrm{L})$ was exceeded in 1 filtered sample. Aluminum was detected in 24 samples, and the SMCL (50 $\mu \mathrm{g} / \mathrm{L})$ was exceeded in three samples. Arsenic was detected in 24 samples, but the MCL for arsenic $(10 \mu \mathrm{g} / \mathrm{L})$ was not exceeded in any sample. Lead was detected in 34 samples, but the MCL $(15 \mu \mathrm{g} / \mathrm{L})$ was not exceeded. Radon-222 was detected in every sample. The proposed USEPA MCL for radon-222 in drinking water (300 pCi/L) was exceeded in 12 samples, but the proposed AMCL (4,000 pCi/L) was not exceeded in any sample.

Fifteen pesticides, including 7 pesticide degradates, were detected in water from 17 of the 35 wells. Most of the concentrations were at or near the detection limits, and no concentration exceeded an MCL. Ten of the samples containing pesticides were from sand and gravel aquifers, and seven were from bedrock aquifers. Sixteen VOCs were detected in 15 samples, and one trichloroethene concentration $(50.8 \mu \mathrm{g} / \mathrm{L})$ exceeded the MCL of $5 \mu \mathrm{g} / \mathrm{L}$ at a private residential well. The presence of total coliform or fecal coliform bacteria is considered a potential violation of New York State MCLs. In this study, total coliform was detected in 19 samples, fecal coliform was detected once, and E. coli was not detected. Heterotrophic plate counts exceeded the MCL of $500 \mathrm{CFU} / \mathrm{mL}$ in three samples. 


\section{References Cited}

Anderson, H.R., Stelz, W.G., Mier, J.B., Miller, T.S., Allen, R.V., and Muller, E.H., 1982, Geohydrology of the glaciolacustrine aquifer in the Fulton area, Oswego County, New York: U.S. Geological Survey Open-File Report 82-83, 7 sheets, scale 1:24,000.

Broughton, J.G., Fisher, D.W., Isachsen, Y.W., Rickard, L.V., and Offield, T.W., 1962, The geology of New York State: Albany, New York State Museum—Geological Survey, Map and Chart Series no. 5, 5 sheets, scale 1:250,000.

Cadwell, D.H., and Muller, E.H., 1986, Surficial geologic map of New York: Albany, New York State Museum-Geological Survey, Map and Chart Series no. 40, 5 sheets, scale 1:250,000, digital compilation by Beckie Ugolini, 1998, from New York State Geological Survey 90-meter Digital Elevation Model.

Cartwright, R.H., and J.A. Ziarno, 1980, Chemical quality of water from community systems in New York, November 1970 to May 1975: U.S. Geological Survey Water-Resources Investigations Report 80-77, $444 \mathrm{p}$.

Coates, D.R., 1966, Glaciated Appalachian Plateau—Till shadows on hills: Science, v. 152, p. 1617-1619.

Cosner, O.J., 1984, Atlas of four selected aquifers in New York: Washington, D.C., U.S. Environmental Protection Agency Report 68-01-6389, 102 p.

Crain, L.J., 1975, Chemical quality of groundwater in the western Oswego River Basin: New York State Department of Environmental Conservation, Basin Planning Report ORB-3, 69 p.

Eckhardt, D.A., Hetcher, K.K., Phillips, P.J., and Miller, T.S., 2001, Pesticides and their metabolites in community water-supply wells of central and central New York, August 1999: U.S. Geological Survey Water-Resources Investigations Report 00-4128, 12 p.

Eckhardt, D.A., Reddy, J.E., and Tamulonis, K.L., 2007, Groundwater quality in the Genesee River Basin, New York, 2005-06: U.S. Geological Survey Open-File Report 2007-1093, 26 p., available at http://pubs.usgs.gov/of/2007/1093.

Eckhardt, D.A., Reddy, J.E., and Tamulonis, K.L., 2008, Groundwater quality in western New York, 2007: U.S. Geological Survey Open-File Report 2008-1140, 36 p., available at http://pubs.usgs.gov/of/2008/1140.

Eckhardt, D.A. and Stackelberg, P.E., 1995, Relation of groundwater quality to land use of Long Island, New York: Groundwater, v. 33, no. 6, p. 1019-1033.

Fairchild, H.L., 1928, Geologic story of the Genesee Valley and drainage history of central New York: Rochester, Gas and Electric News, July 1926 to July 1928.

Furlong, E.T., Anderson, B.D., Werner, S.L., Soliven, P.P., Coffey, L.J., and Burkhardt, M.R., 2001, Methods of analysis by the U.S. Geological Survey National Water Quality Laboratory_Determination of pesticides in water by graphitized carbon-based solid-phase extraction and high-performance liquid chromatography/mass spectrometry: U.S. Geological Survey Water-Resources Investigations Report 01-4134, 73 p.

Hem, J.D., 1985, Study and interpretation of the chemical characteristics of natural water (3d ed.): U.S. Geological Survey Water-Supply Paper 2254, 264 p.

Hetcher-Aguila, K.K., 2004, Groundwater quality in the Chemung River Basin, New York, 2003: U.S. Geological Survey Open-File Report 2004-1329, 19 p., available at http://ny.water.usgs.gov/pubs/of/of041329.

Hetcher-Aguila, K.K. and Eckhardt, D.A., 2006, Groundwater quality in the upper Susquehanna River basin, New York, 2004-05: U.S. Geological Survey Open-File Report 2006-1161, 21 p., available at http://pubs.usgs.gov/of/2006/1161.

Isachsen, Y.W., Landing, Ed, Lauber, J.M., Rickard, L.V., and Rogers, W.B., 2000, Geology of New York: A simplified account (2d ed.): Albany, N.Y., New York State Museum/Geological Survey, 294 p. 
Kantrowitz, I.H., 1970, Chemical quality of groundwater in the eastern Oswego River basin: New York State Department of Environmental Conservation, Basin Planning Report ORB-2, 129 p.

Kontis, A.L., Randall, A.D., and Mazzaferro, D.L., 2004, Regional hydrology and simulation of flow of stratified-drift aquifers in the glaciated northeastern United States: U.S. Geological Survey Professional Paper 1415-C, $156 \mathrm{p}$.

Lee, E.A., and Strahan, A.P., 2003, Determination of acetamide herbicides and their degradation products in water using online solid-phase extraction and liquid chromatography/mass spectrometry: U.S. Geological Survey Open-File Report 03-173, 17 p.

Meyer, M.T., Mills, M.S., and Thurman, E.M., 1993, Automated solid-phase extraction of herbicides from water for gas chromatographic-mass spectrometric analysis: Journal of Chromatography, v. 629, p. 55-59.

Miller, T.S., 1982, Geology and groundwater resources of Oswego County, New York: U.S. Geological Survey Water-Resources Investigations Report 81-60, 37 p.

Miller, T.S., 1988, Unconsolidated aquifers in upstate New York - Finger Lakes sheet: U.S. Geological Survey Water-Resources Investigations Report 87-4122, 1 sheet, scale 1:250,000.

Miller, T.S., 1990, Sand and gravel aquifers of Schuyler County, New York: U.S. Geological Survey Water-Resources Investigations Report 90-4073, 1 sheet, scale 1:48,000.

New York State Department of Health, 2007a, Public water systems - Codes, Rules, and Regulations: Troy, N.Y., Bureau of Public Water Supply Protection, accessed October 2007 at http://www.health.state.ny.us/environmental/water/drinking/part5/subpart5.htm.

New York State Department of Health, 2007b, Public water systems - Maximum Contaminant Levels: Troy, N.Y., Bureau of Public Water Supply Protection, accessed January 2009 at http://www.health.state.ny.us/nysdoh/water/part5/tables.htm.

Nystrom, E.A., 2006, Groundwater quality in the Lake Champlain basin, New York, 2004: U.S. Geological Survey Open-File Report 06-1088, 22 p., available at http://pubs.usgs.gov/of/2006/1088.

Nystrom, E.A., 2007a, Groundwater quality in the Delaware River basin, New York, 2001 \& 2005-2006: U.S. Geological Survey Open-File Report 2007-1098, 37 p., available at http://pubs.usgs.gov/of/2007/1098.

Nystrom, E.A., 2007b, Groundwater quality in the St. Lawrence River basin, New York, 2005-2006: U.S. Geological Survey Open-File Report 2007-1066, 33 p., available at http://pubs.usgs.gov/of/2007/1066.

Nystrom, E.A., 2008, Groundwater quality in the Mohawk River basin, New York, 2006: U.S. Geological Survey Open-File Report 2008-1086, 33 p., available at http://pubs.usgs.gov/of/2008/1086.

Nystrom, E.A., 2009, Groundwater quality in the upper Hudson River basin, New York, 2007: U.S. Geological Survey Open-File Report 2009-1240, 37 p., available at http://pubs.usgs.gov/of/2009/1240.

Pagano, T.S., Terry, D.B., and Ingram, A.W., 1986, Geohydrology of the glacial outwash aquifer in the Baldwinsville area, Seneca River, Onondaga County, New York, 1998: U.S. Geological Survey WaterResources Investigations Report 85-4094, 7 sheets, 1:24,000 scale.

Phillips, P.J., Eckhardt, D.A., Terracciano, S.A., and Rosenmann, L.R., 1999, Pesticides and their metabolites in wells of Suffolk County, New York, 1998: U.S. Geological Survey Water-Resources Investigations Report 99-4095, 12 p.

Randall, A.D., 2001, Hydrogeologic framework of stratified-drift aquifers in the glaciated Northeastern United States: U.S. Geological Survey Professional Paper 1415-B, 179 p.

Sandstrom, M.W., Stroppel, M.E., Foreman, W.T., and Schroeder, M.P., 2001, Methods of analysis by the U.S. Geological Survey National Water Quality Laboratory-Determination of moderate-use pesticides and selected degradates in water by C-18 solid-phase extraction and gas chromatography/mass spectrometry: U.S. Geological Survey Water-Resources Investigations Report 01-4098, 70 p.

Shelton, L.R., 1994, Field guide for collecting and processing stream-water samples for the National Water-Quality Assessment Program: U.S. Geological Survey Open-File Report 94-455, 42 p. 
U.S. Department of Commerce, 2000, Redistricting Census 2000: Washington D.C., Bureau of the Census Geography Division, accessed January 2009 at http://www.census.gov/geo/www/index.html.

U.S. Environmental Protection Agency, 1997, Guidelines for preparation of the comprehensive state water quality assessments, 305(b) reports, and electronic updates: Washington, D.C., Office of Water, EPA 841-B-97-002A and EPA 841-B-97-002B, PL 95-217.

U.S. Environmental Protection Agency, 1998, National primary drinking water regulations-Disinfectants and disinfection byproducts: Washington, D.C., Federal Register, December 16, 1998, v. 63, no. 241, p. 69389-69476.

U.S. Environmental Protection Agency, 2002, Drinking-water advisory-Consumer acceptability advice and health effects analysis on sodium: Washington, D.C., Office of Water, EPA 822-R-02-032, 34 p.

U.S. Environmental Protection Agency, 2004, Proposed radon in drinking water rule: Washington, D.C., Office of Water, accessed January 2009 at http://www.epa.gov/safewater/radon/proposal.html.

U.S. Environmental Protection Agency, 2006, Drinking water standards and health advisories: Washington, D.C., Office of Water, EPA 822-R-06-013, 12 p.

U.S. Geological Survey, variously dated, National field manual for the collection of water-quality data: U.S. Geological Survey Techniques of Water-Resources Investigations, book 9, chap. A1-A9, available online at http://pubs.water.usgs.gov/twri9A.

U.S. Geological Survey, 2007, National Water Quality Laboratory, accessed January 2009 at http://nwql.usgs.gov.

Waller, R.M., and Finch, A.J., 1982, Atlas of eleven selected aquifers in New York: U.S. Geological Survey Open-File Report 82-553, 255 p.

Weist, W.G., and Geist, G.L., 1969, Water resources of the central New York region: New York State Conservation Department, Water Resources Commission Bulletin 64, 58 p.

Wilde, F.D., Radtke, D.B., Gibs, Jacob, and Iwatsubo, R.T., eds., 2004, Processing of water samples: U.S. Geological Survey Techniques of Water-Resources Investigations, book 9, chap. A5, variously paged.

Yager, R.M., Kappel, W.M., and Plummer, L.N., 2007, Halite brine in the Onondaga Trough near Syracuse, New York-Characterization and simulation of variable-density flow: U.S. Geological Survey Scientific Investigations Report 2007-5058, 40 p.

Zaugg, S.D., Sandstrom, M.W., Smith, S.G., and Fehlberg, K.M., 1995, Methods of analysis by the U.S. Geological Survey National Water Quality Laboratory-Determination of pesticides in water by C-18 solid-phase extraction and capillary-column gas chromatography with selective-ion monitoring: U.S. Geological Survey Open-File Report 95-181, 49 p. 
Appendix 
Table A1. Description of wells sampled in the central New York study area, 2007.

[Well locations are shown in figure 1. Well No.: Prefix denotes county: C, Cortland; CM, Chemung; CY, Cayuga; L, Lewis; M, Madison; MO, Monroe; OD, Onondaga; OE, Oneida; OT, Ontario, OW, Oswego; SE, Seneca; SY, Schuyler; TM, Tompkins; WN, Wayne; YT, Yates; number is local well-identification number assigned by U.S. Geological Survey. Basin: CLO, Central Lake Ontario; OSR, Oswego River; ONR, Oneida River; SR, Seneca River. Well type: P, Production well; R, Residential well. -, information not available]

\begin{tabular}{|c|c|c|c|c|c|c|}
\hline $\begin{array}{l}\text { Well } \\
\text { No. }\end{array}$ & $\begin{array}{c}\text { Date } \\
\text { sampled }\end{array}$ & Basin & $\begin{array}{l}\text { Well } \\
\text { type }\end{array}$ & $\begin{array}{l}\text { Well depth, } \\
\text { in feet below } \\
\text { land surface }\end{array}$ & $\begin{array}{l}\text { Casing depth, } \\
\text { in feet below } \\
\text { land surface }\end{array}$ & $\begin{array}{l}\text { Physiographic } \\
\text { province }\end{array}$ \\
\hline \multicolumn{7}{|c|}{ Sand and gravel wells } \\
\hline C 1461 & $12 / 5 / 2007$ & SR & $\mathrm{P}$ & 127 & 100 & Appalachian Plateau \\
\hline CY 10 & $12 / 4 / 2007$ & $\mathrm{SR}$ & $P$ & 31 & 22 & Appalachian Plateau \\
\hline CY 265 & $11 / 13 / 2007$ & CLO & $\mathrm{P}$ & 50 & 50 & Lake Ontario Lowland \\
\hline CY 995 & $9 / 11 / 2007$ & $\mathrm{SR}$ & $\mathrm{R}$ & 80 & 80 & Appalachian Plateau \\
\hline M 291 & $10 / 23 / 2007$ & ONR & $\mathrm{R}$ & 45 & 45 & Lake Ontario Lowland \\
\hline MO 1560 & $8 / 29 / 2007$ & CLO & $\mathrm{R}$ & 40 & 40 & Lake Ontario Lowland \\
\hline OE 1465 & $10 / 10 / 2007$ & ONR & $\mathrm{R}$ & 40 & 40 & Lake Ontario Lowland \\
\hline OE 2848 & 10/10/2007 & ONR & $\mathrm{R}$ & 41 & 41 & Lake Ontario Lowland \\
\hline OT 1864 & $9 / 18 / 2007$ & $\mathrm{SR}$ & $\mathrm{R}$ & 108 & 108 & Appalachian Plateau \\
\hline OW 454 & 9/5/2007 & OSR & $\mathrm{P}$ & 70 & 60 & Lake Ontario Lowland \\
\hline OW 503 & $12 / 19 / 2007$ & ONR & $P$ & 70 & 70 & Lake Ontario Lowland \\
\hline SE 828 & $11 / 28 / 2007$ & $\mathrm{SR}$ & $\mathrm{R}$ & 40 & 40 & Appalachian Plateau \\
\hline SE 1017 & $8 / 23 / 2007$ & SR & $\mathrm{R}$ & 45 & 45 & Appalachian Plateau \\
\hline SY 402 & $8 / 22 / 2007$ & $\mathrm{SR}$ & $\mathrm{P}$ & 33 & 22 & Appalachian Plateau \\
\hline TM 2355 & $8 / 16 / 2007$ & $\mathrm{SR}$ & $\mathrm{R}$ & 145 & 145 & Appalachian Plateau \\
\hline WN 593 & $10 / 31 / 2007$ & CLO & $P$ & 66 & 60 & Lake Ontario Lowland \\
\hline YT 585 & 9/26/2007 & $\mathrm{SR}$ & $\mathrm{R}$ & 39 & 25 & Appalachian Plateau \\
\hline \multicolumn{7}{|c|}{ Bedrock wells } \\
\hline CM 949 & 9/19/2007 & SR & $\mathrm{R}$ & 99 & 73.5 & Appalachian Plateau \\
\hline CY 266 & $12 / 18 / 2007$ & SR & $\mathrm{R}$ & 220 & 20 & Appalachian Plateau \\
\hline CY 380 & 9/11/2007 & SR & $\mathrm{R}$ & 33 & 20 & Lake Ontario Lowland \\
\hline L 304 & $10 / 2 / 2007$ & ONR & $\mathrm{R}$ & 162 & 20 & Tug Hill Upland \\
\hline M 290 & $8 / 28 / 2007$ & ONR & $\mathrm{R}$ & 300 & 50 & Lake Ontario Lowland \\
\hline OD 830 & $11 / 7 / 2007$ & ONR & $\mathrm{R}$ & 102 & 29 & Lake Ontario Lowland \\
\hline OD 1366 & $10 / 3 / 2007$ & $\mathrm{SR}$ & $\mathrm{R}$ & 82 & 20 & Lake Ontario Lowland \\
\hline OD 1870 & $11 / 12 / 2007$ & $\mathrm{SR}$ & $\mathrm{R}$ & 247 & 60 & Appalachian Plateau \\
\hline OD 1900 & $8 / 28 / 2007$ & ONR & $\mathrm{R}$ & 280 & 53 & Appalachian Plateau \\
\hline От 1480 & $10 / 24 / 2007$ & $\mathrm{SR}$ & $\mathrm{R}$ & 95 & 20 & Appalachian Plateau \\
\hline OW 798 & $11 / 7 / 2007$ & ONR & $\mathrm{R}$ & 69 & 48 & Lake Ontario Lowland \\
\hline SE 794 & $10 / 3 / 2007$ & $\mathrm{SR}$ & $\mathrm{R}$ & 40 & 26 & Lake Ontario Lowland \\
\hline SY 1064 & $8 / 23 / 2007$ & $\mathrm{SR}$ & $\mathrm{R}$ & 112 & 16 & Appalachian Plateau \\
\hline TM 1018 & 8/16/2007 & SR & $\mathrm{R}$ & 200 & 50 & Appalachian Plateau \\
\hline TM 2448 & $12 / 17 / 2007$ & SR & $\mathrm{R}$ & 140 & - & Appalachian Plateau \\
\hline WN 814 & 9/18/2007 & CLO & $\mathrm{R}$ & 124 & 56 & Lake Ontario Lowland \\
\hline WN 847 & $11 / 6 / 2007$ & $\mathrm{SR}$ & $\mathrm{R}$ & 45 & 36.75 & Lake Ontario Lowland \\
\hline YT 515 & $10 / 30 / 2007$ & SR & $\mathrm{R}$ & 203 & 19 & Appalachian Plateau \\
\hline
\end{tabular}


Table A2. Compounds for which groundwater samples collected from wells in the central New York study area were analyzed but not detected, 2007.

[NWIS, USGS National Water Information System; $\mu \mathrm{g} / \mathrm{L}$, micrograms per liter]

\begin{tabular}{|c|c|c|}
\hline $\begin{array}{c}\text { NWIS } \\
\text { parameter } \\
\text { code }\end{array}$ & Constituent & $\begin{array}{c}\text { Laboratory } \\
\text { reporting level, } \\
\text { micrograms per liter }\end{array}$ \\
\hline \multicolumn{3}{|c|}{ Trace elements in unfiltered water } \\
\hline 71900 & Mercury & 0.010 \\
\hline \multicolumn{3}{|c|}{ Pesticides in filtered water } \\
\hline 04038 & 2-Chloro-6-ethylamino-4-amino-s-triazine (CEAT) & 0.08 \\
\hline 50470 & 2,4-D methyl ester & 0.20 \\
\hline 39732 & $2,4-\mathrm{D}$ & $0.02-0.04$ \\
\hline 38746 & 2,4-DB & 0.02 \\
\hline 82660 & 2,6-Diethylaniline & 0.002 \\
\hline 49308 & 3-Hydroxy carbofuran & $0.020-0.040$ \\
\hline 49260 & Acetochlor & 0.006 \\
\hline 61029 & Acetochlor ethanesulfonic acid & 0.02 \\
\hline 61030 & Acetochlor oxanilic acid & 0.02 \\
\hline 63782 & Acetochlor second amide & 0.02 \\
\hline 62847 & Acetochlor sulfynilacetic acid & 0.02 \\
\hline 49315 & Acifluorfen & $0.040-0.060$ \\
\hline 46342 & Alachlor & 0.005-0.006 \\
\hline 61031 & Alachlor oxanilic acid & 0.02 \\
\hline 63781 & Alachlor second amide & 0.02 \\
\hline 62848 & Alachlor sulfynilacetic acid & 0.02 \\
\hline 49313 & Aldicarb sulfone & 0.08 \\
\hline 49314 & Aldicarb sulfoxide & $0.040-0.060$ \\
\hline 49312 & Aldicarb & $0.04-0.12$ \\
\hline 34253 & alpha-HCH & 0.002 \\
\hline 82686 & Azinphos-methyl & $0.080-0.120$ \\
\hline 50299 & Bendiocarb & 0.04 \\
\hline 82673 & Benfluralin & $0.004-0.006$ \\
\hline 50300 & Benomyl & $0.020-0.040$ \\
\hline 61693 & Bensulfuron methyl & 0.06 \\
\hline 38711 & Bentazon & $0.02-0.04$ \\
\hline 04029 & Bromacil & $0.02-0.04$ \\
\hline 49311 & Bromoxynil & 0.12 \\
\hline 04028 & Butylate & $0.002-0.004$ \\
\hline 50305 & Caffeine & $0.04-0.06$ \\
\hline 82680 & Carbaryl & 0.060 \\
\hline 82674 & Carbofuran & 0.020 \\
\hline 61188 & Chloramben methyl ester & 0.10 \\
\hline 50306 & Chlorimuron & 0.080 \\
\hline 38933 & Chlorpyrifos & 0.005 \\
\hline 82687 & cis-Permethrin & 0.010 \\
\hline 49305 & Clopyralid & 0.06 \\
\hline
\end{tabular}


Table A2. Compounds for which groundwater samples collected from wells in the central New York study area were analyzed but not detected, 2007.-Continued

[NWIS, USGS National Water Information System; $\mu \mathrm{g} / \mathrm{L}$, micrograms per liter]

\begin{tabular}{|c|c|c|}
\hline $\begin{array}{l}\text { NWIS } \\
\text { parameter } \\
\text { code }\end{array}$ & Constituent & $\begin{array}{c}\text { Laboratory } \\
\text { reporting level, } \\
\text { micrograms per liter }\end{array}$ \\
\hline \multicolumn{3}{|c|}{ Pesticides in filtered water } \\
\hline 04041 & Cyanazine & $0.018-0.020$ \\
\hline 04031 & Cycloate & $0.02-0.06$ \\
\hline 49304 & Dacthal monoacid & 0.02 \\
\hline 82682 & DCPA & 0.003 \\
\hline 63778 & Dechloroacetochlor & 0.02 \\
\hline 63777 & Dechloroalachlor & 0.02 \\
\hline 63779 & Dechlorodimethenamid & 0.02 \\
\hline 63780 & Dechlorometolachlor & 0.02 \\
\hline 62170 & Desulfinyl fipronil & 0.012 \\
\hline 39572 & Diazinon & 0.005 \\
\hline 38442 & Dicamba & $0.04-0.08$ \\
\hline 49302 & Dichlorprop & $0.02-0.04$ \\
\hline 39381 & Dieldrin & $0.009-1.07$ \\
\hline 61951 & Dimethenamid ethanesulfonic acid & 0.02 \\
\hline 62482 & Dimethenamid oxanilic acid & 0.02 \\
\hline 61588 & Dimethenamid & 0.02 \\
\hline 49301 & Dinoseb & 0.04 \\
\hline 04033 & Diphenamid & 0.04 \\
\hline 82677 & Disulfoton & $0.02-0.11$ \\
\hline 49300 & Diuron & 0.04 \\
\hline 82668 & EPTC & 0.002 \\
\hline 82663 & Ethalfluralin & 0.009 \\
\hline 82672 & Ethoprop & 0.012 \\
\hline 62169 & Desulfinylfipronil amide & 0.029 \\
\hline 62167 & Fipronil sulfide & 0.013 \\
\hline 62168 & Fipronil sulfone & 0.024 \\
\hline 62166 & Fipronil & $0.016-0.020$ \\
\hline 61952 & Flufenacet ethanesulfonic acid & 0.02 \\
\hline 62483 & Flufenacet oxanilic acid & 0.02 \\
\hline 62481 & Flufenacet & 0.02 \\
\hline 61694 & Flumetsulam & 0.06 \\
\hline 38811 & Fluometuron & 0.04 \\
\hline 04095 & Fonofos & $0.006-0.010$ \\
\hline 63784 & Hydroxyacetochlor & 0.02 \\
\hline 63783 & Hydroxyalachlor & 0.02 \\
\hline 63785 & Hydroxymetolachlor & 0.02 \\
\hline 64045 & Hydroxydimethenamid & 0.02 \\
\hline 50356 & Imazaquin & 0.04 \\
\hline 61695 & Imidacloprid & 0.060 \\
\hline 39341 & Lindane & $0.004-0.006$ \\
\hline
\end{tabular}


Table A2. Compounds for which groundwater samples collected from wells in the central New York study area were analyzed but not detected, 2007.-Continued

[NWIS, USGS National Water Information System; $\mu \mathrm{g} / \mathrm{L}$, micrograms per liter]

\begin{tabular}{|c|c|c|}
\hline $\begin{array}{c}\text { NWIS } \\
\text { parameter } \\
\text { code }\end{array}$ & Constituent & $\begin{array}{c}\text { Laboratory } \\
\text { reporting level, } \\
\text { micrograms per liter }\end{array}$ \\
\hline \multicolumn{3}{|c|}{ Pesticides in filtered water } \\
\hline 82666 & Linuron & 0.060 \\
\hline 39532 & Malathion & 0.016 \\
\hline 38482 & MCРA & 0.06 \\
\hline 38487 & МСРВ & $0.06-0.20$ \\
\hline 50359 & Metalaxyl & $0.02-0.04$ \\
\hline 38501 & Methiocarb & 0.040 \\
\hline 49296 & Methomyl & $0.060-0.120$ \\
\hline 82667 & Methyl parathion & 0.008 \\
\hline 82630 & Metribuzin & 0.012 \\
\hline 61697 & Metsulfuron & $0.07-0.14$ \\
\hline 82671 & Molinate & 0.002 \\
\hline 61692 & $N$-(4-Chlorophenyl)- $N$ '-methylurea & 0.14 \\
\hline 82684 & Napropamide & 0.018 \\
\hline 49294 & Neburon & 0.02 \\
\hline 50364 & Nicosulfuron & 0.10 \\
\hline 49292 & Oryzalin & 0.04 \\
\hline 38866 & Oxamyl & $0.04-0.12$ \\
\hline 34653 & $p, p^{\prime}-\mathrm{DDE}$ & 0.003 \\
\hline 39542 & Parathion & 0.010 \\
\hline 82669 & Pebulate & $0.004-0.008$ \\
\hline 82683 & Pendimethalin & $0.012-0.020$ \\
\hline 82664 & Phorate & $0.020-0.040$ \\
\hline 49291 & Picloram & 0.12 \\
\hline 82676 & Propyzamide & 0.004 \\
\hline 04024 & Propachlor & $0.006-0.010$ \\
\hline 62766 & Propachlor ethanesulfonic acid & 0.05 \\
\hline 62767 & Propachlor oxanilic acid & 0.02 \\
\hline 82679 & Propanil & $0.006-0.011$ \\
\hline 82685 & Propargite & $0.02-0.04$ \\
\hline 49236 & Propham & $0.040-0.060$ \\
\hline 50471 & Propiconazole & $0.04-0.06$ \\
\hline 38538 & Propoxur & 0.040 \\
\hline 38548 & Siduron & $0.02-0.04$ \\
\hline 50337 & Sulfometuron & 0.060 \\
\hline 82665 & Terbacil & $0.018-0.040$ \\
\hline 82675 & Terbufos & $0.01-0.02$ \\
\hline 82681 & Thiobencarb & 0.010 \\
\hline 82678 & Triallate & 0.006 \\
\hline 49235 & Triclopyr & $0.04-0.08$ \\
\hline 82661 & Trifluralin & 0.006 \\
\hline
\end{tabular}


Table A2. Compounds for which groundwater samples collected from wells in the central New York study area were analyzed but not detected, 2007.-Continued

[NWIS, USGS National Water Information System; $\mu \mathrm{g} / \mathrm{L}$, micrograms per liter]

\begin{tabular}{llc}
\hline $\begin{array}{c}\text { NWIS } \\
\text { parameter } \\
\text { code }\end{array}$ & \multicolumn{1}{c}{ Constituent } & $\begin{array}{c}\text { Laboratory } \\
\text { reporting level, } \\
\text { micrograms per liter }\end{array}$ \\
\hline \multicolumn{2}{c}{ Volatile organic and phenolic compounds, in unfiltered water } \\
\hline 77652 & 1,1,2-Trichloro-1,2,2-trifluoroethane (CFC-113) \\
34536 & 1,2-Dichlorobenzene & 0.1 \\
32103 & 1,2-Dichloroethane & 0.1 \\
34541 & 1,2-Dichloropropane & 0.2 \\
34566 & 1,3-Dichlorobenzene & 0.1 \\
34571 & 1,4-Dichlorobenzene & 0.1 \\
34301 & Chlorobenzene & 0.1 \\
34668 & Dichlorodifluoromethane & 0.1 \\
81576 & Diethyl ether & 0.2 \\
81577 & Diisopropyl ether & 0.2 \\
78032 & Methyl tert-butyl ether & 0.2 \\
50005 & Methyl tert-pentyl ether & 0.2 \\
77128 & Styrene & 0.2 \\
50004 & tert-Butyl ethyl ether & 0.1 \\
32102 & Tetrachloromethane & 0.1 \\
34546 & trans-1,2-Dichloroethene & 0.2 \\
34488 & Trichlorofluoromethane & 0.1 \\
39175 & Vinyl Choride & 0.2 \\
32730 & Phenolic Compounds & 0.2 \\
& & 4 \\
\hline
\end{tabular}


Table A3. Physical properties of groundwater samples from the central New York study area, 2007.

[Well locations are shown in figure 1. Well No.: Prefix denotes county: C, Cortland; CM, Chemung; CY, Cayuga; L, Lewis; M, Madison; MO, Monroe; OD, Onondaga; OE, Oneida; OT, Ontario, OW, Oswego; SE, Seneca; SY, Schuyler; TM, Tompkins; WN, Wayne; YT, Yates; number is local well-identification number assigned by U.S. Geological Survey. mg/L, milligrams per liter; <, less than; $\mu \mathrm{S} / \mathrm{cm}$, microsiemens per centimeter at $25^{\circ} \mathrm{Celsius;}$ (00080), USGS National Water Information System (NWIS) parameter code; -, no data. Bold values exceed one or more drinking-water standards]

\begin{tabular}{|c|c|c|c|c|c|c|}
\hline $\begin{array}{l}\text { Well } \\
\text { No. }\end{array}$ & $\begin{array}{l}\text { Water color, } \\
\text { filtered, } \\
\text { platinum-cobalt } \\
\text { units }(00080)\end{array}$ & $\begin{array}{l}\text { Dissolved-oxygen } \\
\text { concentration, } \\
\text { field, mg/L } \\
(00300)\end{array}$ & $\begin{array}{c}\mathrm{pH}, \text { field, } \\
\text { standard units } \\
(00400)\end{array}$ & $\begin{array}{c}\text { Specific } \\
\text { conductance, field, } \\
\mu \mathrm{S} / \mathrm{cm}(00095)\end{array}$ & $\begin{array}{l}\text { Water } \\
\text { temperature, } \\
\text { degrees } \\
\text { Celsius } \\
(00010)\end{array}$ & $\begin{array}{l}\text { Hydrogen } \\
\text { sulfide } \\
\text { (71875) }\end{array}$ \\
\hline \multicolumn{7}{|c|}{ Sand and gravel wells } \\
\hline C 1461 & 5 & 9.1 & 7.3 & 483 & 8.3 & Absent \\
\hline CY 10 & 5 & 5.5 & 7.2 & 658 & 12.8 & Absent \\
\hline CY 265 & 8 & 7.6 & 7.7 & 315 & 10.0 & Absent \\
\hline CY 995 & 5 & 0.4 & 7.5 & 488 & 16.9 & Absent \\
\hline M 291 & 10 & $<0.3$ & 7.2 & 830 & 17.2 & Absent \\
\hline MO 1560 & 2 & 6.0 & 7.3 & 1,090 & 16.4 & Absent \\
\hline OE 1465 & 5 & $<0.3$ & 7.3 & 2,500 & 14.1 & Present \\
\hline OE 2848 & 5 & $<0.3$ & 7.3 & 534 & 17.7 & Present \\
\hline OT 1864 & 8 & 0.3 & 7.3 & 736 & 14.8 & Absent \\
\hline OW 454 & 5 & 0.3 & 7.5 & 1,060 & 13.4 & Absent \\
\hline OW 503 & 2 & 2.9 & 8.3 & 141 & 8.7 & Absent \\
\hline SE 828 & 5 & 4.5 & 7.2 & 602 & 14.6 & Absent \\
\hline SE 1017 & 5 & 0.4 & 7.1 & 1,300 & 18.7 & Absent \\
\hline SY 402 & 5 & 1.3 & 7.2 & 622 & 14.9 & Present \\
\hline TM 2355 & 5 & 6.4 & 7.6 & 339 & 19.4 & Absent \\
\hline WN 593 & 5 & $<0.3$ & 7.6 & 490 & 10.4 & Present \\
\hline YT 585 & 5 & 0.5 & 7.1 & 805 & 19.5 & Absent \\
\hline \multicolumn{7}{|c|}{ Bedrock wells } \\
\hline CM 949 & 5 & $<0.3$ & 7.5 & 379 & 14.8 & Present \\
\hline CY 266 & 8 & 4.4 & 7.3 & 889 & 10.6 & Absent \\
\hline CY 380 & 2 & 3.5 & 7.1 & 654 & 18.7 & Absent \\
\hline L 304 & 2 & 1.9 & 7.3 & 309 & 14.8 & Absent \\
\hline M 290 & 2 & 5.0 & 7.3 & 1,060 & 23.2 & Absent \\
\hline OD 830 & 5 & 1.2 & 7.7 & 320 & 14.2 & Absent \\
\hline OD 1366 & 8 & 1.0 & 7.4 & 1,090 & 14.7 & Absent \\
\hline OD 1870 & 8 & $<0.3$ & 7.5 & 608 & 11.0 & Present \\
\hline OD 1900 & 5 & $<0.3$ & 7.7 & 500 & 16.5 & Absent \\
\hline OT 1480 & 10 & $<0.3$ & 6.8 & 401 & 13.7 & Absent \\
\hline OW 798 & 12 & 6.5 & 8.2 & 179 & 10.8 & Absent \\
\hline SE 794 & 5 & 1.8 & 7.0 & 1,540 & 19.6 & Absent \\
\hline SY 1064 & 5 & 0.5 & 7.5 & 444 & 19.5 & Absent \\
\hline TM 1018 & 5 & $<0.3$ & 7.8 & 950 & 21.5 & Present \\
\hline TM 2448 & 25 & 2.7 & 7.5 & 580 & 9.8 & Absent \\
\hline WN 814 & 5 & 0.4 & 7.5 & 301 & 18.4 & Absent \\
\hline WN 847 & 8 & $<0.3$ & 7.3 & 740 & 12.4 & Present \\
\hline YT 515 & 15 & 0.9 & 7.0 & 11,700 & 12.8 & Absent \\
\hline
\end{tabular}


Table A4. Concentrations of inorganic constituents in groundwater samples from the central New York study area, 2007.

[Well locations are shown in figure 1. Well No.: Prefix denotes county: C, Cortland; CM, Chemung; CY, Cayuga; L, Lewis; M, Madison; MO, Monroe; OD, Onondaga; OE, Oneida; OT, Ontario, OW, Oswego; SE, Seneca; SY, Schuyler; TM, Tompkins; WN, Wayne; YT, Yates; number is local well-identification number assigned by U.S. Geological Survey. Acid-neutralizing capacity, unfiltered and alkalinity, filtered: Fixed-endpoint titration at pH 4.5. Bicarbonate, filtered: Calculated from alkalinity. mg/L, milligrams per liter; (00900), USGS National Water Information System (NWIS) parameter code; $\mathrm{CaCO}_{3}$, calcium carbonate. Bold values exceed one or more drinking-water standards]

\begin{tabular}{|c|c|c|c|c|c|c|c|}
\hline $\begin{array}{l}\text { Well } \\
\text { No. }\end{array}$ & $\begin{array}{l}\text { Hardness, filtered, } \\
\text { mg/L as } \mathrm{CaCO}_{3} \\
(00900)\end{array}$ & $\begin{array}{c}\text { Calcium, } \\
\text { filtered, mg/L } \\
(00915)\end{array}$ & $\begin{array}{l}\text { Magnesium, } \\
\text { filtered, mg/L } \\
(00925)\end{array}$ & $\begin{array}{l}\text { Potassium, } \\
\text { filtered, mg/L } \\
(00935)\end{array}$ & $\begin{array}{c}\text { Sodium, } \\
\text { filtered, mg/L } \\
(00930)\end{array}$ & $\begin{array}{l}\text { Acid-neutralizing } \\
\text { capacity, unfiltered, } \\
\text { mg/L as } \mathrm{CaCO}_{3} \\
(90410)\end{array}$ & $\begin{array}{c}\text { Alkalinity, } \\
\text { filtered, } \\
\text { mg/L as } \mathrm{CaCO}_{3} \\
\text { (29801) }\end{array}$ \\
\hline \multicolumn{8}{|c|}{ Sand and gravel wells } \\
\hline C 1461 & 200 & 58.2 & 12.9 & 0.91 & 18.3 & 166 & 167 \\
\hline CY 10 & 320 & 91.1 & 22.2 & 1.74 & 14.2 & 273 & 273 \\
\hline CY 265 & 150 & 41.4 & 11.1 & 0.93 & 3.48 & 137 & 137 \\
\hline CY 995 & 210 & 45.4 & 22.3 & 1.62 & 21.8 & 240 & 241 \\
\hline M 291 & 320 & 78.0 & 30.7 & 0.80 & 47.6 & 310 & 309 \\
\hline MO 1560 & 280 & 74.0 & 23.0 & 1.51 & 126 & 283 & 283 \\
\hline OE 1465 & 430 & 93.8 & 47.8 & 5.62 & 343 & 264 & 263 \\
\hline OE 2848 & 260 & 51.4 & 31.9 & 4.68 & 13.7 & 290 & 290 \\
\hline OT 1864 & 400 & 94.2 & 39.8 & 1.08 & 6.79 & 298 & 299 \\
\hline OW 454 & 250 & 73.1 & 17.1 & 3.29 & 111 & 224 & 224 \\
\hline OW 503 & 68 & 18.2 & 5.46 & 0.41 & 1.20 & 64 & 64 \\
\hline SE 828 & 330 & 101 & 17.9 & 0.77 & 2.82 & 265 & 267 \\
\hline SE 1017 & 490 & 132 & 39.8 & 1.72 & 87.9 & 365 & 365 \\
\hline SY 402 & 200 & 62.3 & 11.8 & 2.37 & 42.9 & 163 & 162 \\
\hline TM 2355 & 150 & 42.7 & 10.7 & 0.83 & 13.3 & 161 & 163 \\
\hline WN 593 & 240 & 59.6 & 22.7 & 0.99 & 7.06 & 177 & 177 \\
\hline YT 585 & 420 & 105 & 38.1 & 1.31 & 8.82 & 313 & 314 \\
\hline \multicolumn{8}{|c|}{ Bedrock wells } \\
\hline CM 949 & 140 & 39.7 & 10.0 & 0.88 & 28.9 & 177 & 178 \\
\hline CY 266 & 350 & 99.2 & 25.0 & 2.70 & 40.5 & 207 & 209 \\
\hline CY 380 & 340 & 88.1 & 28.8 & 4.62 & 3.10 & 291 & 292 \\
\hline L 304 & 150 & 35.5 & 14.9 & 1.21 & 5.81 & 151 & 152 \\
\hline M 290 & 540 & 162 & 33.7 & 1.25 & 14.6 & 239 & 240 \\
\hline OD 830 & 130 & 29.5 & 13.4 & 5.60 & 6.28 & 112 & 112 \\
\hline OD 1366 & 350 & 93.3 & 28.2 & 37.7 & 95.1 & 194 & 199 \\
\hline OD 1870 & 170 & 51.1 & 11.2 & 1.31 & 59.7 & 230 & 230 \\
\hline OD 1900 & 140 & 31.3 & 13.8 & 1.79 & 65.1 & 198 & 226 \\
\hline OT 1480 & 180 & 50.0 & 12.6 & 1.36 & 18.2 & 211 & 212 \\
\hline OW 798 & 84 & 15.0 & 11.3 & 0.65 & 2.14 & 83 & 83 \\
\hline SE 794 & 870 & 262 & 51.7 & 3.58 & 21.2 & 285 & 285 \\
\hline SY 1064 & 140 & 37.7 & 9.97 & 0.85 & 46.6 & 202 & 203 \\
\hline TM 1018 & 100 & 27.5 & 7.64 & 0.73 & 159 & 201 & 202 \\
\hline TM 2448 & 260 & 70.0 & 20.1 & 2.14 & 27.1 & 252 & 245 \\
\hline WN 814 & 140 & 37.9 & 11.0 & 3.46 & 6.35 & 135 & 136 \\
\hline WN 847 & 310 & 68.7 & 34.5 & 3.11 & 4.19 & 242 & 242 \\
\hline YT 515 & 1,700 & 489 & 115 & 7.47 & 1,870 & 608 & 608 \\
\hline
\end{tabular}


Table A4. Concentrations of inorganic constituents in groundwater samples from the central New York study area, 2007.-Continued

[Well locations are shown in figure 1. Well No.: Prefix denotes county: C, Cortland; CM, Chemung; CY, Cayuga; L, Lewis; M, Madison; MO, Monroe; OD, Onondaga; OE, Oneida; OT, Ontario, OW, Oswego; SE, Seneca; SY, Schuyler; TM, Tompkins; WN, Wayne; YT, Yates; number is local well-identification number assigned by U.S. Geological Survey. Acid-neutralizing capacity, unfiltered and alkalinity, filtered: Fixed-endpoint titration at pH 4.5. Bicarbonate, filtered: Calculated from alkalinity. mg/L, milligrams per liter; (29805), USGS National Water Information System (NWIS) parameter code; $\mathrm{CaCO}_{3}$, calcium carbonate. Bold values exceed one or more drinking-water standards]

\begin{tabular}{|c|c|c|c|c|c|c|}
\hline $\begin{array}{l}\text { Well } \\
\text { No. }\end{array}$ & $\begin{array}{c}\text { Bicarbonate, } \\
\text { filtered, } \\
\mathrm{mg} / \mathrm{L} \text { as CaCO } \\
\text { (29805) }\end{array}$ & $\begin{array}{c}\text { Chloride, } \\
\text { filtered, } \mathrm{mg} / \mathrm{L} \\
(00940)\end{array}$ & $\begin{array}{l}\text { Fluoride, } \\
\text { filtered, mg/L } \\
(00950)\end{array}$ & $\begin{array}{c}\text { Silica, } \\
\text { filtered, mg/L } \\
(00955)\end{array}$ & $\begin{array}{c}\text { Sulfate, } \\
\text { filtered, mg/L } \\
(00945)\end{array}$ & $\begin{array}{c}\text { Residue on } \\
\text { evaporation, at } \\
180^{\circ} \text { Celsius, } \\
\text { filtered, mg/L } \\
(70300)\end{array}$ \\
\hline \multicolumn{7}{|c|}{ Sand and gravel wells } \\
\hline C 1461 & 203 & 33.0 & E 0.07 & 7.33 & 14.0 & 267 \\
\hline CY 10 & 333 & 26.7 & 0.14 & 5.48 & 35.3 & 383 \\
\hline CY 265 & 167 & 5.23 & $<0.12$ & 9.33 & 12.8 & 165 \\
\hline CY 995 & 293 & 17.4 & 0.42 & 14.4 & $<.18$ & 259 \\
\hline M 291 & 378 & 72.8 & E 0.11 & 12.9 & 22.0 & 464 \\
\hline MO 1560 & 345 & 160 & 0.12 & 10.0 & 40.6 & 596 \\
\hline OE 1465 & 322 & 663 & E .06 & 11.2 & 29.2 & 1,400 \\
\hline OE 2848 & 354 & 8.96 & 0.15 & 14.7 & 3.80 & 304 \\
\hline OT 1864 & 364 & 17.1 & 0.19 & 14.6 & 95.9 & 470 \\
\hline OW 454 & 273 & 190 & 0.11 & 11.6 & 16.5 & 557 \\
\hline OW 503 & 78 & 1.49 & Е 0.08 & 6.64 & 7.14 & 74 \\
\hline SE 828 & 323 & 6.98 & E 0.10 & 7.60 & 26.1 & 348 \\
\hline SE 1017 & 445 & 135 & 0.10 & 12.0 & 139 & 822 \\
\hline SY 402 & 199 & 77.6 & E 0.10 & 5.73 & 29.5 & 343 \\
\hline TM 2355 & 196 & 2.10 & 0.29 & 13.2 & 15.9 & 196 \\
\hline WN 593 & 216 & 16.4 & 0.27 & 9.29 & 55.2 & 296 \\
\hline YT 585 & 382 & 28.8 & 0.21 & 14.2 & 94.9 & 504 \\
\hline \multicolumn{7}{|c|}{ Bedrock wells } \\
\hline CM 949 & 216 & 17.5 & 0.19 & 11.5 & 5.27 & 219 \\
\hline CY 266 & 253 & 48.2 & 0.19 & 7.15 & 160 & 541 \\
\hline CY 380 & 355 & 10.3 & 0.12 & 6.77 & 32.0 & 373 \\
\hline L 304 & 184 & 2.74 & Е 0.09 & 10.4 & 11.7 & 170 \\
\hline M 290 & 292 & 46.1 & 0.46 & 6.29 & 269 & 723 \\
\hline OD 830 & 137 & 14.0 & Е 0.11 & 7.67 & 26.6 & 181 \\
\hline OD 1366 & 237 & 159 & 0.92 & 7.77 & 217 & 789 \\
\hline OD 1870 & 281 & 38.7 & E 0.11 & 8.30 & 27.2 & 321 \\
\hline OD 1900 & 242 & 6.11 & 0.45 & 9.33 & 40.8 & 294 \\
\hline OT 1480 & 257 & 1.50 & 0.19 & 13.9 & 9.04 & 234 \\
\hline OW 798 & 101 & 0.68 & Е 0.07 & 7.76 & 10.2 & 98 \\
\hline SE 794 & 348 & 38.2 & 0.20 & 5.88 & 543 & 1,180 \\
\hline SY 1064 & 246 & 13.5 & 0.31 & 9.58 & 18.5 & 269 \\
\hline TM 1018 & 245 & 179 & 0.43 & 6.95 & 0.44 & 510 \\
\hline TM 2448 & 307 & 15.6 & 0.20 & 14.6 & 47.9 & 334 \\
\hline WN 814 & 165 & 2.22 & 0.12 & 11.0 & 21.0 & 168 \\
\hline WN 847 & 295 & 54.8 & 0.25 & 13.9 & 76.6 & 478 \\
\hline YT 515 & 742 & 3,380 & 0.27 & 9.56 & Е 0.14 & 7,130 \\
\hline
\end{tabular}


Table A5. Concentrations of nutrients and total organic carbon in groundwater samples from the central New York study area, 2007.

[Well locations are shown in figure 1. Well No.: Prefix denotes county: C, Cortland; CM, Chemung; CY, Cayuga; L, Lewis; M, Madison; MO, Monroe; OD, Onondaga; OE, Oneida; OT, Ontario, OW, Oswego; SE, Seneca; SY, Schuyler; TM, Tompkins; WN, Wayne; YT, Yates; number is local well-identification number assigned by U.S. Geological Survey. mg/L, milligrams per liter; N, nitrogen; P, phosphorus; <, less than; (00623), National Water Information System (NWIS) parameter code; E, estimated value-constituent was detected in the sample but with low or inconsistent recovery]

\begin{tabular}{|c|c|c|c|c|c|c|}
\hline $\begin{array}{l}\text { Well } \\
\text { No. }\end{array}$ & $\begin{array}{c}\text { Ammonia plus } \\
\text { organic nitrogen, } \\
\text { filtered, } \mathrm{mg} / \mathrm{L} \text { as } \mathrm{N} \\
(00623)\end{array}$ & $\begin{array}{l}\text { Ammonia, } \\
\text { filtered, } \\
\text { mg/L as N } \\
(00608)\end{array}$ & $\begin{array}{l}\text { Nitrate plus } \\
\text { nitrite, filtered, } \\
\text { mg/L as N } \\
(00631)\end{array}$ & $\begin{array}{l}\text { Nitrite, filtered, } \\
\text { mg/L as N } \\
(00613)\end{array}$ & $\begin{array}{l}\text { Orthophosphate, } \\
\text { filtered, } \\
\text { mg/L as P } \\
\text { (00671) }\end{array}$ & $\begin{array}{c}\text { Total organic } \\
\text { carbon, } \\
\text { unfiltered, mg/L } \\
(00680)\end{array}$ \\
\hline \multicolumn{7}{|c|}{ Sand and gravel wells } \\
\hline C 1461 & $<0.14$ & $<0.020$ & 4.70 & $<0.002$ & E 0.003 & $<1.0$ \\
\hline CY 10 & $<0.14$ & $<0.020$ & 2.79 & $<0.002$ & E 0.004 & $<1.0$ \\
\hline CY 265 & $<0.14$ & $<0.020$ & 2.11 & $<0.002$ & E 0.004 & $<1.0$ \\
\hline CY 995 & 0.28 & 0.282 & $<0.06$ & E 0.002 & 0.024 & 1.2 \\
\hline M 291 & $<0.14$ & Е 0.017 & $<0.04$ & $<0.002$ & E 0.004 & 2.4 \\
\hline MO 1560 & $<0.10$ & $<0.020$ & 0.58 & $<0.002$ & E 0.005 & 1.8 \\
\hline OE 1465 & 0.22 & 0.141 & $<0.04$ & Е 0.002 & E 0.005 & 1.2 \\
\hline OE 2848 & 0.37 & 0.335 & $<0.04$ & $<0.002$ & 0.011 & 1.2 \\
\hline OT 1864 & E 0.05 & 0.043 & $<0.06$ & $<0.002$ & 0.007 & 1.1 \\
\hline OW 454 & 0.14 & 0.110 & 0.25 & E 0.002 & E 0.006 & 1.7 \\
\hline OW 503 & $<0.14$ & $<0.020$ & 0.25 & $<0.002$ & E 0.003 & $<1.0$ \\
\hline SE 828 & $<0.14$ & $<0.020$ & 7.34 & $<0.002$ & E 0.004 & $<1.0$ \\
\hline SE 1017 & 0.12 & 0.031 & 0.25 & 0.089 & 0.009 & 2.1 \\
\hline SY 402 & Е 0.06 & E 0.020 & 0.51 & 0.003 & 0.007 & 1.5 \\
\hline TM 2355 & 0.16 & 0.151 & $<0.06$ & $<0.002$ & 0.031 & $<1.0$ \\
\hline WN 593 & 0.21 & 0.020 & $<0.04$ & $<0.002$ & E 0.005 & $<1.0$ \\
\hline YT 585 & E 0.09 & Е 0.020 & $<0.06$ & $<0.002$ & 0.008 & $<1.0$ \\
\hline \multicolumn{7}{|c|}{ Bedrock wells } \\
\hline CM 949 & 0.18 & 0.176 & $<0.06$ & $<0.002$ & 0.047 & $<1.0$ \\
\hline CY 266 & 0.38 & 0.271 & 1.23 & 0.039 & E 0.004 & 1.4 \\
\hline CY 380 & Е 0.09 & $<0.020$ & 5.35 & E 0.001 & E 0.005 & 1.7 \\
\hline L 304 & $<0.14$ & $<0.020$ & 0.65 & $<0.002$ & E 0.004 & $<1.0$ \\
\hline M 290 & $<0.10$ & $<0.020$ & 1.30 & $<0.002$ & E 0.004 & 1.1 \\
\hline OD 830 & $<0.14$ & 0.041 & 0.10 & $<0.002$ & $<0.006$ & 1.0 \\
\hline OD 1366 & 2.5 & 2.50 & $<0.04$ & $<0.002$ & E 0.004 & $<1.0$ \\
\hline OD 1870 & 0.49 & 0.468 & $<0.04$ & $<0.002$ & 0.006 & $<1.1$ \\
\hline OD 1900 & 0.32 & 0.259 & $<0.06$ & $<0.002$ & E 0.005 & 1.3 \\
\hline OT 1480 & 0.22 & 0.208 & $<0.04$ & $<0.002$ & 0.006 & $<1.0$ \\
\hline OW 798 & $<0.14$ & $<0.020$ & 0.08 & $<0.002$ & Е 0.003 & $<1.0$ \\
\hline SE 794 & $<0.14$ & 0.030 & 4.53 & Е 0.001 & E 0.004 & $<1.0$ \\
\hline SY 1064 & Е 0.10 & 0.073 & 0.10 & Е 0.001 & 0.011 & $<1.0$ \\
\hline TM 1018 & 0.48 & 0.425 & $<0.06$ & $<0.002$ & 0.012 & $<1.0$ \\
\hline TM 2448 & 0.16 & 0.146 & $<0.04$ & $<0.002$ & Е 0.005 & $<1.0$ \\
\hline WN 814 & E 0.05 & 0.047 & 0.07 & $<0.002$ & 0.006 & $<1.0$ \\
\hline WN 847 & 0.33 & 0.064 & $<0.04$ & $<0.002$ & E 0.005 & 2.7 \\
\hline YT 515 & 4.5 & 4.33 & $<0.04$ & E 0.001 & 0.034 & 1.7 \\
\hline
\end{tabular}


Table A6. Concentrations of trace elements and radon-222 in groundwater samples from the central New York study area, 2007.

[Well locations are shown in figure 1. Well No.: Prefix denotes county: C, Cortland; CM, Chemung; CY, Cayuga; L, Lewis; M, Madison; MO, Monroe; OD, Onondaga; OE, Oneida; OT, Ontario, OW, Oswego; SE, Seneca; SY, Schuyler; TM, Tompkins; WN, Wayne; YT, Yates; number is local well-identification number assigned by U.S. Geological Survey. $\mu \mathrm{g} / \mathrm{L}$, micrograms per liter; (01105), USGS National Water Information System (NWIS) parameter code; <, less than; E, estimated value-constituent was detected in the sample but with low or inconsistent recovery. Bold values exceed one or more drinking-water standards]

\begin{tabular}{|c|c|c|c|c|c|c|c|c|}
\hline $\begin{array}{c}\text { Well } \\
\text { number }\end{array}$ & $\begin{array}{c}\text { Aluminum, } \\
\text { unfiltered, } \mu \mathrm{g} / \mathrm{L} \\
(01105)\end{array}$ & $\begin{array}{c}\text { Antimony, } \\
\text { unfiltered, } \mu \mathrm{g} / \mathrm{L} \\
(01097)\end{array}$ & $\begin{array}{c}\text { Arsenic, } \\
\text { unfiltered, } \\
\mu \mathrm{g} / \mathrm{L}(01002)\end{array}$ & $\begin{array}{c}\text { Barium, } \\
\text { unfiltered, } \\
\mu \mathrm{g} / \mathrm{L}(01007)\end{array}$ & $\begin{array}{c}\text { Beryllium, } \\
\text { unfiltered, } \\
\text { g/L (01012) }\end{array}$ & $\begin{array}{c}\text { Boron, } \\
\text { filtered, } \mu \mathrm{g} / \mathrm{L} \\
(01020)\end{array}$ & $\begin{array}{c}\text { Cadmium, } \\
\text { unfiltered, } \mu \mathrm{g} / \mathrm{L} \\
(01027)\end{array}$ & $\begin{array}{c}\text { Chromium, } \\
\text { unfiltered, } \mu \mathrm{g} / \mathrm{L} \\
(01034)\end{array}$ \\
\hline \multicolumn{9}{|c|}{ Sand and gravel wells } \\
\hline C 1461 & $<4$ & $<0.1$ & $<0.60$ & 30.8 & $<0.04$ & 12 & $<0.01$ & E 0.26 \\
\hline CY 10 & 14 & $<0.1$ & $<0.60$ & 63.2 & $<0.04$ & 18 & $<0.01$ & $<0.40$ \\
\hline CY 265 & $<4$ & $<0.1$ & $<0.60$ & 164 & $<0.04$ & 11 & $<0.01$ & E 0.32 \\
\hline CY 995 & 41 & $<0.2$ & 0.23 & 572 & $<0.06$ & 111 & $<0.02$ & $<0.60$ \\
\hline M 291 & $<4$ & $<0.1$ & $<0.60$ & 365 & $<0.04$ & 24 & $<0.01$ & $<0.40$ \\
\hline MO 1560 & $<2$ & $<0.2$ & Е 0.12 & 52.0 & $<0.06$ & 45 & $<0.02$ & Е 0.48 \\
\hline OE 1465 & $<8$ & $<0.3$ & $<1.2$ & 462 & $<0.08$ & 60 & 0.06 & $<0.80$ \\
\hline OE 2848 & E 3 & $<0.1$ & $<0.60$ & 215 & $<0.04$ & 85 & $<0.01$ & $<0.40$ \\
\hline OT 1864 & $<2$ & $<0.2$ & 7.2 & 63.8 & $<0.06$ & 9.5 & $<0.02$ & $<0.60$ \\
\hline OW 454 & E 2 & $<0.2$ & Е 0.19 & 630 & $<0.06$ & 20 & E 0.01 & $<0.60$ \\
\hline OW 503 & E 3 & $<0.1$ & 1.3 & 10.5 & $<0.04$ & 6.0 & $<0.01$ & Е 0.27 \\
\hline SE 828 & 24 & 0.2 & $<0.60$ & 55.6 & $<0.04$ & 21 & $<0.01$ & $<0.40$ \\
\hline SE 1017 & $<2$ & $<0.2$ & 0.71 & 66.7 & $<0.06$ & 31 & $<0.02$ & $<0.60$ \\
\hline SY 402 & $<2$ & $<0.2$ & 0.37 & 25.7 & $<0.06$ & 29 & 0.03 & $<0.60$ \\
\hline TM 2355 & 33 & $<0.2$ & 3.8 & 203 & $<0.06$ & 34 & E0.01 & $<0.60$ \\
\hline WN 593 & E 4 & $<0.1$ & $<0.60$ & 353 & $<0.04$ & 12 & Е 0.01 & $<0.40$ \\
\hline YT 585 & 4 & $<0.2$ & 2.3 & 39.7 & $<0.06$ & 14 & 0.02 & $<0.60$ \\
\hline \multicolumn{9}{|c|}{ Bedrock wells } \\
\hline CM 949 & 15 & $<0.2$ & Е 0.13 & 911 & $<0.06$ & 62 & $<0.02$ & $<0.60$ \\
\hline CY 266 & 4,830 & 0.4 & 8.7 & 233 & 0.2 & 502 & $<0.01$ & 7.4 \\
\hline CY 380 & E 2 & $<0.2$ & E 0.17 & 94.0 & $<0.06$ & 24 & $<0.02$ & $<0.60$ \\
\hline L 304 & 88 & Е 0.1 & Е 0.49 & 148 & $<0.04$ & 30 & Е 0.01 & Е 0.32 \\
\hline M 290 & 9 & E 0.2 & 0.25 & 81.6 & $<0.06$ & 46 & $<0.02$ & $<0.60$ \\
\hline OD 830 & $<4$ & 0.3 & 0.93 & 71.2 & $<0.04$ & 92 & 0.02 & $<0.40$ \\
\hline OD 1366 & 10 & Е 0.1 & 1.8 & 12.3 & $<0.04$ & 3,140 & Е 0.01 & $<0.40$ \\
\hline OD 1870 & 9 & $<0.1$ & $<0.60$ & 286 & $<0.04$ & 294 & $<0.01$ & $<0.40$ \\
\hline OD 1900 & 2 & $<0.2$ & Е 0.10 & 302 & $<0.06$ & 761 & $<0.02$ & $<0.60$ \\
\hline OT 1480 & $<4$ & $<0.1$ & 0.85 & 331 & $<0.04$ & 139 & $<0.01$ & $<0.40$ \\
\hline OW 798 & 5 & $<0.1$ & 1.1 & 21.9 & $<0.04$ & 5.0 & $<0.01$ & 0.43 \\
\hline SE 794 & 20 & Е 0.1 & $<0.60$ & 14.4 & $<0.04$ & 45 & $<0.01$ & Е 0.22 \\
\hline SY 1064 & E 1 & $<0.2$ & 0.29 & 122 & $<0.06$ & 265 & Е 0.01 & $<0.60$ \\
\hline TM 1018 & 256 & $<0.2$ & 0.23 & 1,290 & $<0.06$ & 346 & $<0.02$ & E 0.46 \\
\hline TM 2448 & 46 & 0.2 & Е 0.49 & 54.7 & $<0.04$ & 113 & 0.02 & $<0.40$ \\
\hline WN 814 & E 2 & $<0.2$ & 3.1 & 60.8 & $<0.06$ & 38 & $<0.02$ & $<0.60$ \\
\hline WN 847 & $<4$ & 0.5 & 2.2 & 85.5 & $<0.04$ & 113 & Е 0.01 & $<0.40$ \\
\hline YT 515 & E 15 & $<0.7$ & $<3.0$ & 10,400 & $<0.20$ & 872 & $<0.07$ & 44.4 \\
\hline
\end{tabular}


Table A6. Concentrations of trace elements and radon-222 in groundwater samples from the central New York study area, 2007.-Continued

[Well locations are shown in figure 1. Well No.: Prefix denotes county: C, Cortland; CM, Chemung; CY, Cayuga; L, Lewis; M, Madison; MO, Monroe; OD, Onondaga; OE, Oneida; OT, Ontario, OW, Oswego; SE, Seneca; SY, Schuyler; TM, Tompkins; WN, Wayne; YT, Yates; number is local well-identification number assigned by U.S. Geological Survey. $\mu \mathrm{g} / \mathrm{L}$, micrograms per liter; (01037), USGS National Water Information System (NWIS) parameter code; <, less than; E, estimated value-constituent was detected in the sample but with low or inconsistent recovery; $\mathrm{M}$, measured but not quantified. Bold values exceed one or more drinking-water standards]

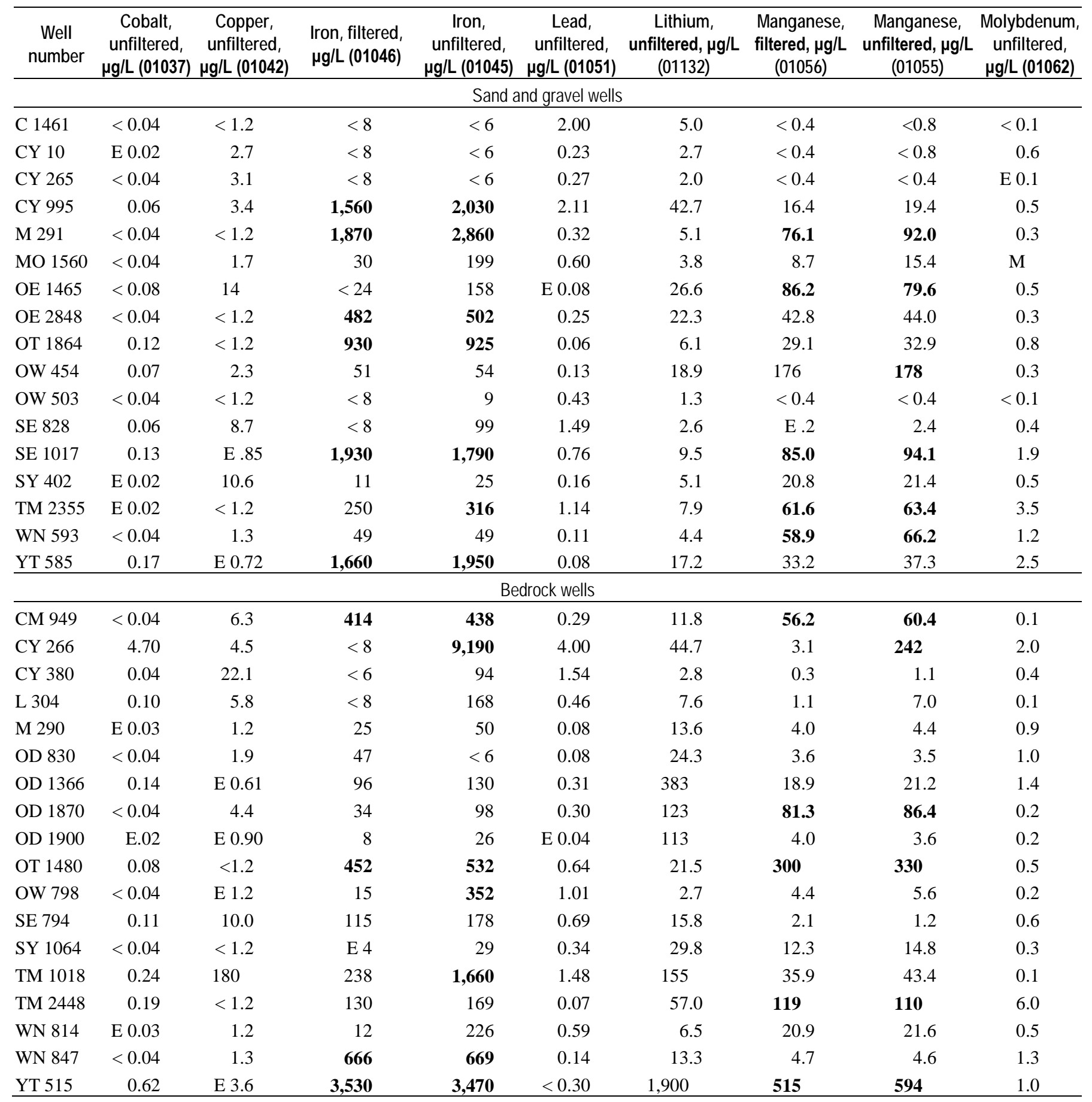


Table A6. Concentrations of trace elements and radon-222 in groundwater samples from the central New York study area, 2007.-Continued

[Well locations are shown in figure 1. Well No.: Prefix denotes county: C, Cortland; CM, Chemung; CY, Cayuga; L, Lewis; M, Madison; MO, Monroe; OD, Onondaga; OE, Oneida; OT, Ontario, OW, Oswego; SE, Seneca; SY, Schuyler; TM, Tompkins; WN, Wayne; YT, Yates; number is local well-identification number assigned by U.S. Geological Survey. $\mu \mathrm{g} / \mathrm{L}$, micrograms per liter; (01067), USGS National Water Information System (NWIS) parameter code; <, less than; E, estimated value-constituent was detected in the sample but with low or inconsistent recovery; M, measured but not quantified. Bold values exceed one or more drinking-water standards]

\begin{tabular}{|c|c|c|c|c|c|c|c|c|}
\hline $\begin{array}{c}\text { Well } \\
\text { number }\end{array}$ & $\begin{array}{c}\text { Nickel, } \\
\text { unfiltered, } \\
\mu \mathrm{g} / \mathrm{L} \\
(01067)\end{array}$ & $\begin{array}{c}\text { Selenium, } \\
\text { unfiltered, } \\
\mu \mathrm{g} / \mathrm{L} \\
(01147)\end{array}$ & $\begin{array}{c}\text { Silver, } \\
\text { unfiltered, } \\
\mu \mathrm{g} / \mathrm{L} \\
(01077)\end{array}$ & $\begin{array}{c}\text { Strontium, } \\
\text { unfiltered, } \\
\mu \mathrm{g} / \mathrm{L} \\
(01082)\end{array}$ & $\begin{array}{c}\text { Thallium, } \\
\text { unfiltered, } \\
\mu \mathrm{g} / \mathrm{L} \\
(01059)\end{array}$ & $\begin{array}{l}\text { Radon-222, } \\
\text { unfiltered, } \\
\text { picocuries } \\
\text { per liter } \\
\text { (pCi/L) } \\
(82303)\end{array}$ & $\begin{array}{c}\text { Uranium, } \\
\text { (natural), } \\
\text { unfiltered, } \\
\mu \mathrm{g} / \mathrm{L} \\
(\mathbf{2 8 0 1 1 )}\end{array}$ & $\begin{array}{c}\text { Zinc, } \\
\text { unfiltered, } \\
\mu g / L \\
(01092)\end{array}$ \\
\hline \multicolumn{9}{|c|}{ Sand and gravel wells } \\
\hline C 1461 & 0.18 & E 0.04 & $<0.02$ & 97.2 & $<0.08$ & 550 & 0.137 & $<2.0$ \\
\hline CY 10 & 0.40 & 0.20 & $<0.02$ & 180 & E 0.05 & 450 & 0.756 & 2.0 \\
\hline CY 265 & 0.16 & E 0.05 & $<0.02$ & 116 & $<0.08$ & 450 & 0.117 & 5.1 \\
\hline CY 995 & E 0.14 & $<0.08$ & $<0.02$ & 979 & $<0.18$ & 80 & $<0.012$ & 7.3 \\
\hline M 291 & 0.24 & $<0.08$ & $<0.02$ & 127 & $<0.08$ & 120 & 0.167 & 23.1 \\
\hline MO 1560 & Е 0.16 & 0.21 & $<0.02$ & 180 & $<0.18$ & 120 & 0.300 & 3.7 \\
\hline OE 1465 & 0.24 & $<0.16$ & $<0.04$ & 975 & $<0.16$ & 170 & $<0.040$ & E 3.6 \\
\hline OE 2848 & $<0.12$ & $<0.08$ & $<0.02$ & 1,050 & $<0.08$ & 70 & $<0.020$ & $<2.0$ \\
\hline OT 1864 & E0.13 & $<0.08$ & $<0.02$ & 360 & $<0.18$ & 350 & 0.595 & 2.8 \\
\hline OW 454 & 0.27 & $<0.08$ & $<0.02$ & 1,100 & $<0.18$ & 580 & 0.297 & 2.9 \\
\hline OW 503 & 0.23 & $<0.08$ & $<0.02$ & 32.9 & $<0.08$ & 260 & 0.047 & 2.2 \\
\hline SE 828 & 1.50 & 0.16 & $<0.02$ & 119 & $<0.08$ & 260 & 0.468 & 4.4 \\
\hline SE 1017 & 0.81 & $<0.08$ & $<0.02$ & 247 & $<0.18$ & 80 & 2.36 & 2.6 \\
\hline SY 402 & E0.12 & Е 0.07 & $<0.02$ & 152 & $<0.18$ & 680 & 0.410 & 8.4 \\
\hline TM 2355 & Е 0.11 & $<0.08$ & $<0.02$ & 388 & $<0.18$ & 160 & 0.043 & E 1.5 \\
\hline WN 593 & 0.12 & $<0.08$ & $<0.02$ & 178 & $<0.08$ & 80 & 0.331 & E 1.8 \\
\hline YT 585 & 0.33 & $<0.08$ & $<0.02$ & 609 & $<0.18$ & 90 & 0.641 & 4.1 \\
\hline \multicolumn{9}{|c|}{ Bedrock wells } \\
\hline CM 949 & E 0.08 & $<0.08$ & $<0.02$ & 587 & $<0.18$ & 330 & $<.012$ & 3.3 \\
\hline CY 266 & 10.6 & Е 0.05 & $<0.02$ & 657 & $<0.08$ & 70 & 0.257 & 19.4 \\
\hline CY 380 & 0.98 & 0.18 & $<0.02$ & 116 & $<0.18$ & 400 & 0.836 & 15.8 \\
\hline L 304 & 0.28 & $<0.08$ & $<0.02$ & 127 & $<0.08$ & 120 & 0.079 & 4.6 \\
\hline M 290 & 1.0 & 0.16 & $<0.02$ & 9,230 & $<0.18$ & 680 & 0.837 & 24.5 \\
\hline OD 830 & 0.40 & E 0.05 & $<0.02$ & 2,000 & $<0.08$ & 1,000 & 0.791 & 6.8 \\
\hline OD 1366 & 0.29 & $<0.08$ & $<0.02$ & 4,020 & $<0.08$ & 220 & 0.069 & 74.9 \\
\hline OD 1870 & 0.19 & $<0.08$ & $<0.02$ & 2,420 & $<0.08$ & 80 & 0.150 & 4.0 \\
\hline OD 1900 & 0.31 & 0.73 & $<0.02$ & 2,230 & $<0.18$ & 80 & 0.032 & 9.8 \\
\hline OT 1480 & 0.20 & $<0.08$ & $<0.02$ & 414 & $<0.08$ & 350 & 0.041 & 3.1 \\
\hline OW 798 & $<0.12$ & 0.09 & $<0.02$ & 46.5 & $<0.08$ & 140 & 0.445 & E 1.1 \\
\hline SE 794 & 1.30 & 0.24 & $<0.02$ & 1,660 & $<0.08$ & 200 & 0.515 & 4.7 \\
\hline SY 1064 & $<0.16$ & $<0.08$ & $<0.02$ & 406 & $<0.18$ & 220 & 0.236 & 33.5 \\
\hline TM 1018 & 0.48 & $<0.08$ & $<0.02$ & 1,430 & $<0.18$ & 280 & 0.018 & 4.6 \\
\hline TM 2448 & 1.50 & 5.9 & $<0.02$ & 4,450 & $<0.08$ & 90 & 28.3 & $<2.0$ \\
\hline WN 814 & $<0.16$ & $<0.08$ & $<0.02$ & 167 & $<0.18$ & 190 & 0.176 & 4.5 \\
\hline WN 847 & 0.16 & $<0.08$ & 0.06 & 53,800 & $<0.08$ & 740 & 0.266 & 39.2 \\
\hline YT 515 & 25.4 & $<0.40$ & $<0.10$ & 23,600 & $<0.40$ & 210 & $<.100$ & E 8.7 \\
\hline
\end{tabular}


Table A7. Concentrations of pesticides detected in groundwater samples from the central New York study area, 2007.

[Well locations are shown in figure 1. Well No.: Prefix denotes county: C, Cortland; CM, Chemung; CY, Cayuga; L, Lewis; M, Madison; MO, Monroe; OD, Onondaga; OE, Oneida; OT, Ontario, OW, Oswego; SE, Seneca; SY, Schuyler; TM, Tompkins; WN, Wayne; YT, Yates; number is local well-identification number assigned by U.S. Geological Survey. $\mu \mathrm{g} / \mathrm{L}$, micrograms per liter; <, less than; (04040), USGS National Water Information System (NWIS) parameter code; CIAT, 2Chloro-4-isopropylamino-6-amino-s-triazine; OIET, 2-Hydroxy-4-isopropylamino-6-ethylamino-s-triazine; ESA, ethanesulfanic acid; E, estimated value-constituent was detected in the sample but with low or inconsistent recovery; $\mathrm{M}$, measured but not quantified; -, not analyzed]

\begin{tabular}{|c|c|c|c|c|c|c|c|c|}
\hline $\begin{array}{l}\text { Well } \\
\text { No. }\end{array}$ & $\begin{array}{c}\text { CIAT, } \\
\text { filtered, } \\
\mu \mathrm{g} / \mathrm{L}(04040)\end{array}$ & $\begin{array}{c}\text { OIET } \\
\text { filtered, } \\
\mu \mathrm{g} / \mathrm{L}(50355)\end{array}$ & $\begin{array}{c}\text { 2-[(2-Ethyl-6- } \\
\text { methylphenyl) } \\
\text { amino]-2-oxo- } \\
\text { ESA, filtered, } \\
\mu \mathrm{g} / \mathrm{L}(62850)\end{array}$ & $\begin{array}{l}\text { Alachlor ESA } \\
2 \mathrm{~d} \text { amide } \\
\text { filtered, } \mu \mathrm{g} / \mathrm{L} \\
(62849)\end{array}$ & $\begin{array}{l}\text { Alachlor ESA, } \\
\text { filtered, } \mu \mathrm{g} / \mathrm{L} \\
(50009)\end{array}$ & $\begin{array}{l}\text { Imazethapyr } \\
\text { filtered, } \mu \mathrm{g} / \mathrm{L} \\
(50407)\end{array}$ & $\begin{array}{c}\text { Atrazine, } \\
\text { filtered, } \mu \mathrm{g} / \mathrm{L} \\
(39632)\end{array}$ & $\begin{array}{c}\text { Norflurazon } \\
\text { filtered, } \mu \mathrm{g} / \mathrm{L} \\
(49293)\end{array}$ \\
\hline \multicolumn{9}{|c|}{ Sand and gravel wells } \\
\hline C 1461 & E 0.003 & $<0.040$ & $<0.02$ & $<0.02$ & 0.02 & $<0.04$ & $<0.007$ & $<0.02$ \\
\hline CY 10 & E 0.055 & 0.040 & 0.02 & $<0.02$ & 0.03 & $<0.04$ & 0.088 & $<0.02$ \\
\hline CY 265 & E 0.024 & $<0.040$ & $<0.02$ & 0.02 & 0.76 & $<0.04$ & 0.018 & $<0.02$ \\
\hline CY 995 & $<0.014$ & $<0.080$ & $<0.02$ & $<0.02$ & $<0.02$ & $<0.04$ & $<0.007$ & $<0.04$ \\
\hline M 291 & $<0.014$ & $<0.040$ & $<0.02$ & $<0.02$ & $<0.02$ & $<0.04$ & $<0.007$ & $<0.02$ \\
\hline MO 1560 & $<0.014$ & $<0.080$ & $<0.02$ & $<0.02$ & 0.02 & $<0.04$ & $<0.007$ & $<0.04$ \\
\hline OE 1465 & $<0.014$ & $<0.040$ & $<0.02$ & $<0.02$ & $<0.02$ & $<0.04$ & $<0.007$ & $<0.02$ \\
\hline OE 2848 & $<0.014$ & $<0.040$ & $<0.02$ & $<0.02$ & $<0.02$ & $<0.04$ & $<0.007$ & $<0.02$ \\
\hline OT 1864 & $<0.014$ & - & $<0.02$ & $<0.02$ & $<0.02$ & $<0.04$ & $<0.007$ & $<0.04$ \\
\hline OW 454 & E0 .009 & $<0.080$ & $<0.02$ & $<0.02$ & $<0.02$ & $<0.04$ & 0.023 & $<0.04$ \\
\hline OW 503 & $<0.014$ & $<0.040$ & $<0.02$ & $<0.02$ & $<0.02$ & $<0.04$ & $<0.007$ & $<0.02$ \\
\hline SE 828 & E 0.023 & $<0.040$ & $<0.02$ & $<0.02$ & $<0.02$ & $<0.04$ & $<0.007$ & $<0.02$ \\
\hline SE 1017 & $<0.014$ & $<0.080$ & $<0.02$ & $<0.02$ & $<0.02$ & $<0.04$ & $<0.007$ & $<0.04$ \\
\hline SY 402 & E 0.008 & $<0.080$ & $<0.02$ & 0.02 & $<0.02$ & $<0.04$ & 0.013 & M \\
\hline TM 2355 & $<0.014$ & $<0.080$ & $<0.02$ & $<0.02$ & $<0.02$ & $<0.04$ & $<0.007$ & $<0.04$ \\
\hline WN 593 & E 0.001 & $<0.040$ & $<0.02$ & $<0.02$ & 0.15 & $<0.04$ & $<0.007$ & $<0.02$ \\
\hline YT 585 & $<0.014$ & $<0.080$ & $<0.02$ & $<0.02$ & $<0.02$ & $<0.04$ & $<0.007$ & $<0.04$ \\
\hline \multicolumn{9}{|c|}{ Bedrock wells } \\
\hline CM 949 & $<0.014$ & - & $<0.02$ & $<0.02$ & $<0.02$ & $<0.04$ & $<0.007$ & $<0.04$ \\
\hline CY 266 & $<0.014$ & $<0.040$ & $<0.02$ & $<0.02$ & $<0.02$ & $<0.04$ & E 0.003 & $<0.02$ \\
\hline CY 380 & E 0.075 & $<0.080$ & $<0.02$ & $<0.02$ & $<0.02$ & $<0.04$ & 0.011 & $<0.04$ \\
\hline L 304 & $<0.014$ & $<0.040$ & $<0.02$ & $<0.02$ & $<0.02$ & $<0.04$ & $<0.007$ & $<0.02$ \\
\hline M 290 & $<0.014$ & $<0.080$ & $<0.02$ & $<0.02$ & $<0.02$ & $<0.04$ & $<0.007$ & $<0.04$ \\
\hline OD 830 & $<0.014$ & $<0.040$ & $<0.02$ & $<0.02$ & $<0.02$ & $<0.04$ & $<0.007$ & $<0.02$ \\
\hline OD 1366 & Е 0.004 & $<0.040$ & $<0.02$ & $<0.02$ & $<0.02$ & $<0.04$ & $<0.007$ & $<0.02$ \\
\hline OD 1870 & $<0.014$ & $<0.040$ & $<0.02$ & $<0.02$ & $<0.02$ & $<0.04$ & $<0.007$ & $<0.02$ \\
\hline OD 1900 & $<0.014$ & $<0.080$ & $<0.02$ & $<0.02$ & $<0.02$ & $\mathrm{M}$ & $<0.007$ & $<0.04$ \\
\hline OT 1480 & $<0.014$ & $<0.040$ & $<0.02$ & $<0.02$ & 0.02 & $<0.04$ & $<0.007$ & $<0.02$ \\
\hline OW 798 & $<0.014$ & $<0.040$ & $<0.02$ & $<0.02$ & $<0.02$ & $<0.04$ & $<0.007$ & $<0.02$ \\
\hline SE 794 & $<0.014$ & $<0.040$ & $<0.02$ & $<0.02$ & $<0.02$ & $<0.04$ & $<0.007$ & $<0.02$ \\
\hline SY 1064 & $<0.014$ & $<0.080$ & $<0.02$ & $<0.02$ & $<0.02$ & $<0.04$ & $<0.007$ & $<0.04$ \\
\hline TM 1018 & $<0.014$ & $<0.080$ & $<0.02$ & $<0.02$ & $<0.02$ & $<0.04$ & $<0.007$ & $<0.04$ \\
\hline TM 2448 & $<0.014$ & $<0.040$ & $<0.02$ & $<0.02$ & $<0.02$ & $<0.04$ & $<0.007$ & $<0.02$ \\
\hline WN 814 & $<0.014$ & - & $<0.02$ & $<0.02$ & $<0.02$ & $<0.04$ & $<0.007$ & $<0.04$ \\
\hline WN 847 & $<0.014$ & $<0.040$ & 0.02 & $<0.02$ & 0.07 & $<0.04$ & $<0.007$ & $<0.02$ \\
\hline YT 515 & - & $<0.040$ & $<0.02$ & $<0.02$ & $<0.02$ & $<0.04$ & - & $<0.02$ \\
\hline
\end{tabular}


Table A7. Concentrations of pesticides detected in groundwater samples from the central New York study area, 2007.-Continued

[Well locations are shown in figure 1. Well No.: Prefix denotes county: C, Cortland; CM, Chemung; CY, Cayuga; L, Lewis; M, Madison; MO, Monroe; OD, Onondaga; OE, Oneida; OT, Ontario, OW, Oswego; SE, Seneca; SY, Schuyler; TM, Tompkins; WN, Wayne; YT, Yates; number is local well-identification number assigned by U.S. Geological Survey. $\mu \mathrm{g} / \mathrm{L}$, micrograms per liter; <, less than; (49297), USGS National Water Information System (NWIS) parameter code; CIAT, 2-Chloro-4-isopropylamino-6-amino-s-triazine; OIET, 2-Hydroxy-4-isopropylamino6-ethylamino-s-triazine; ESA, ethanesulfanic acid; E, estimated value-constituent was detected in the sample but with low or inconsistent recovery; M, measured but not quantified; -, not analyzed]

\begin{tabular}{|c|c|c|c|c|c|c|c|}
\hline $\begin{array}{l}\text { Well } \\
\text { No. }\end{array}$ & $\begin{array}{c}\text { Fenuron } \\
\text { filtered, } \mu \mathrm{g} / \mathrm{L} \\
(49297)\end{array}$ & $\begin{array}{c}\text { Metola- } \\
\text { chlor ESA, } \\
\text { filtered, } \mu \mathrm{g} / \mathrm{L} \\
(61043)\end{array}$ & $\begin{array}{c}\text { Metola- } \\
\text { chlor OA, } \\
\text { filtered, } \mu \mathrm{g} / \mathrm{L} \\
(61044)\end{array}$ & $\begin{array}{c}\text { Metola- } \\
\text { chlor, filtered, } \\
\mu \mathrm{g} / \mathrm{L} \\
(39415)\end{array}$ & $\begin{array}{l}\text { Prometon } \\
\text { filtered, } \mu \mathrm{g} / \mathrm{L} \\
(04037)\end{array}$ & $\begin{array}{l}\text { Simazine, } \\
\text { filtered, } \mu \mathrm{g} / \mathrm{L} \\
(04035)\end{array}$ & $\begin{array}{c}\text { Tebuthiron } \\
\text { filtered, } \mu g / \mathrm{L} \\
(82670)\end{array}$ \\
\hline \multicolumn{8}{|c|}{ Sand and gravel wells } \\
\hline C 1461 & $<0.04$ & 1.51 & $<0.02$ & $<0.010$ & $<0.01$ & $<0.006$ & $<0.02$ \\
\hline CY 10 & $<0.04$ & 0.68 & 0.22 & E 0.006 & 0.03 & 0.006 & $<0.02$ \\
\hline CY 265 & $<0.04$ & $<0.02$ & $<0.02$ & $<0.010$ & $<0.01$ & $<0.006$ & $<0.02$ \\
\hline CY 995 & 0.05 & $<0.02$ & $<0.02$ & $<0.010$ & $<0.01$ & $<0.006$ & $<0.02$ \\
\hline M 291 & $<0.04$ & $<0.02$ & $<0.02$ & $<0.010$ & $<0.01$ & $<0.006$ & $<0.05$ \\
\hline MO 1560 & $<0.04$ & $<0.02$ & $<0.02$ & $<0.010$ & $<0.01$ & $<0.006$ & $<0.02$ \\
\hline OE 1465 & $<0.04$ & $<0.02$ & $<0.02$ & $<0.010$ & $<0.01$ & $<0.006$ & $<0.02$ \\
\hline OE 2848 & $<0.04$ & $<0.02$ & $<0.02$ & $<0.010$ & $<0.01$ & $<0.006$ & $<0.02$ \\
\hline OT 1864 & $<0.04$ & $<0.02$ & $<0.02$ & $<0.010$ & $<0.01$ & $<0.006$ & $<0.02$ \\
\hline OW 454 & $<0.04$ & $<0.02$ & $<0.02$ & $<0.010$ & $<0.01$ & $<0.006$ & 0.02 \\
\hline OW 503 & $<0.04$ & $<0.02$ & $<0.02$ & $<0.010$ & $<0.01$ & $<0.006$ & $<0.02$ \\
\hline SE 828 & $<0.04$ & $<0.02$ & $<0.02$ & $<0.010$ & $<0.01$ & $<0.006$ & E 0.02 \\
\hline SE 1017 & $<0.04$ & $<0.02$ & 0.02 & $<0.010$ & $<0.01$ & $<0.006$ & $<0.02$ \\
\hline SY 402 & $<0.04$ & $<0.02$ & $<0.02$ & $<0.010$ & $<0.01$ & 0.011 & $<0.02$ \\
\hline TM 2355 & $<0.04$ & $<0.02$ & $<0.02$ & $<0.010$ & $<0.01$ & $<0.006$ & $<0.02$ \\
\hline WN 593 & $<0.04$ & 0.07 & 0.08 & $<0.010$ & $<0.01$ & $<0.006$ & $<0.02$ \\
\hline YT 585 & $<0.04$ & $<0.02$ & $<0.02$ & $<0.010$ & $<0.01$ & $<0.006$ & $<0.02$ \\
\hline \multicolumn{8}{|c|}{ Bedrock wells } \\
\hline CM 949 & $<0.04$ & $<0.02$ & $<0.02$ & $<0.010$ & $<0.01$ & $<0.006$ & $<0.02$ \\
\hline CY 266 & $<0.04$ & $<0.02$ & $<0.02$ & $<0.010$ & $<0.01$ & $<0.006$ & $<0.02$ \\
\hline CY 380 & $<0.04$ & $<0.02$ & $<0.02$ & $<0.010$ & $<0.01$ & $<0.006$ & $<0.02$ \\
\hline L 304 & $<0.04$ & $<0.02$ & $<0.02$ & $<0.010$ & $<0.01$ & $<0.006$ & $<0.02$ \\
\hline M 290 & $<0.04$ & $<0.02$ & $<0.02$ & $<0.010$ & $<0.01$ & $<0.006$ & $<0.02$ \\
\hline OD 830 & $<0.04$ & $<0.02$ & $<0.02$ & $<0.010$ & $<0.01$ & $<0.006$ & $<0.02$ \\
\hline OD 1366 & $<0.04$ & $<0.02$ & $<0.02$ & $<0.010$ & $<0.01$ & $<0.006$ & $<0.02$ \\
\hline OD 1870 & $<0.04$ & $<0.02$ & $<0.02$ & $<0.010$ & $<0.01$ & $<0.006$ & $<0.02$ \\
\hline OD 1900 & $<0.04$ & $<0.02$ & $<0.02$ & $<0.010$ & $<0.01$ & $<0.006$ & $<0.02$ \\
\hline OT 1480 & $<0.04$ & $<0.02$ & $<0.02$ & $<0.010$ & $<0.01$ & $<0.006$ & $<0.02$ \\
\hline OW 798 & $<0.04$ & $<0.02$ & $<0.02$ & $<0.010$ & $<0.01$ & $<0.006$ & $<0.02$ \\
\hline SE 794 & $<0.04$ & 0.08 & $<0.02$ & $<0.010$ & $<0.01$ & $<0.006$ & $<0.02$ \\
\hline SY 1064 & $<0.04$ & $<0.02$ & $<0.02$ & $<0.010$ & $<0.01$ & $<0.006$ & $<0.02$ \\
\hline TM 1018 & $<0.04$ & $<0.02$ & $<0.02$ & $<0.010$ & $<0.01$ & $<0.006$ & $<0.02$ \\
\hline TM 2448 & $<0.04$ & $<0.02$ & $<0.02$ & $<0.010$ & $<0.01$ & $<0.006$ & $<0.02$ \\
\hline WN 814 & $<0.04$ & $<0.02$ & $<0.02$ & $<0.010$ & $<0.01$ & $<0.006$ & $<0.02$ \\
\hline WN 847 & $<0.04$ & $<0.02$ & 0.07 & $<0.010$ & $<0.01$ & $<0.006$ & $<0.02$ \\
\hline YT 515 & $<0.04$ & $<0.02$ & $<0.02$ & $<0.010$ & $<0.01$ & - & - \\
\hline
\end{tabular}


Table A8. Concentrations of volatile organic compounds in groundwater samples from the central New York study area, 2007.

[Well locations are shown in figure 1. Well No.: Prefix denotes county: C, Cortland; CM, Chemung; CY, Cayuga; L, Lewis; M, Madison; MO, Monroe; OD, Onondaga; OE, Oneida; OT, Ontario, OW, Oswego; SE, Seneca; SY, Schuyler; TM, Tompkins; WN, Wayne; YT, Yates; number is local well-identification number assigned by U.S. Geological Survey. $\mu \mathrm{g} / \mathrm{L}$, micrograms per liter; <, less than; (34506), USGS National Water Information System parameter code; E, estimated valueconstituent was detected in the sample but with low or inconsistent recovery. Bold values exceed one or more drinking-water standards]

\begin{tabular}{|c|c|c|c|c|c|c|c|c|}
\hline $\begin{array}{l}\text { Well } \\
\text { No. }\end{array}$ & $\begin{array}{l}\text { 1,1,1-Trichloro- } \\
\text { ethane, } \\
\text { unfiltered, } \mu \mathrm{g} / \mathrm{L} \\
(34506)\end{array}$ & $\begin{array}{l}\text { 1,1-Dichloro- } \\
\text { ethane, } \\
\text { unfiltered, } \mu \mathrm{g} / \mathrm{L} \\
(34496)\end{array}$ & $\begin{array}{l}\text { 1,1-Dichloro- } \\
\text { ethene, } \\
\text { unfiltered, } \mu \mathrm{g} / \mathrm{L} \\
\text { (34501) }\end{array}$ & $\begin{array}{c}\text { Dichloro- } \\
\text { methane, } \\
\text { unfiltered, } \\
\text { g/L (34423) }\end{array}$ & $\begin{array}{l}\text { Bromodichloro- } \\
\text { methane, } \\
\text { unfiltered, } \mu \mathrm{g} / \mathrm{L} \\
(32101)\end{array}$ & $\begin{array}{c}\text { Tribromo- } \\
\text { methane, } \\
\text { unfiltered, } \\
\mu \mathrm{g} / \mathrm{L}(32104)\end{array}$ & $\begin{array}{c}\text { Dibromo- } \\
\text { chloro- } \\
\text { methane, } \\
\text { unfiltered, } \\
\mu \mathrm{g} / \mathrm{L}(32105)\end{array}$ & $\begin{array}{c}\text { Trichloro- } \\
\text { methane, } \\
\text { unfiltered, } \\
\mu \mathrm{g} / \mathrm{L} \\
(32106)\end{array}$ \\
\hline \multicolumn{9}{|c|}{ Sand and gravel wells } \\
\hline C 1461 & $<0.1$ & $<0.1$ & $<0.1$ & $<0.2$ & $<0.1$ & $<0.2$ & $<0.2$ & $<0.1$ \\
\hline CY 10 & $<0.1$ & $<0.1$ & $<0.1$ & $<0.2$ & 0.3 & $<0.2$ & 0.2 & 0.4 \\
\hline CY 265 & $<0.1$ & $<0.1$ & $<0.1$ & $<0.2$ & $<0.1$ & $<0.2$ & $<0.2$ & $<0.1$ \\
\hline CY 995 & $<0.1$ & $<0.1$ & $<0.1$ & $<0.2$ & $<0.1$ & $<0.2$ & $<0.2$ & $<0.1$ \\
\hline M 291 & $<0.1$ & $<0.1$ & $<0.1$ & $<0.2$ & $<0.1$ & $<0.2$ & $<0.2$ & 0.5 \\
\hline MO 1560 & $<0.1$ & $<0.1$ & $<0.1$ & $<0.2$ & $<0.1$ & $<0.2$ & $<0.2$ & $<0.1$ \\
\hline OE 1465 & $<0.1$ & $<0.1$ & $<0.1$ & 0.2 & 0.9 & 0.5 & 1.0 & 1.6 \\
\hline OE 2848 & $<0.1$ & $<0.1$ & $<0.1$ & $<0.2$ & $<0.1$ & $<0.2$ & $<0.2$ & $<0.1$ \\
\hline OT 1864 & $<0.1$ & $<0.1$ & $<0.1$ & $<0.2$ & $<0.1$ & $<0.2$ & $<0.2$ & $<0.1$ \\
\hline OW 454 & 2.0 & 0.3 & 0.4 & $<0.2$ & $<0.1$ & $<0.2$ & $<0.2$ & $<0.1$ \\
\hline OW 503 & $<0.1$ & $<0.1$ & $<0.1$ & $<0.2$ & $<0.1$ & $<0.2$ & $<0.2$ & $<0.1$ \\
\hline SE 828 & $<0.1$ & $<0.1$ & $<0.1$ & $<0.2$ & $<0.1$ & $<0.2$ & $<0.2$ & $<0.1$ \\
\hline SE 1017 & $<0.1$ & $<0.1$ & $<0.1$ & $<0.2$ & $<0.1$ & $<0.2$ & $<0.2$ & $<0.1$ \\
\hline SY 402 & $<0.1$ & $<0.1$ & $<0.1$ & $<0.2$ & $<0.1$ & $<0.2$ & $<0.2$ & $<0.1$ \\
\hline TM 2355 & $<0.1$ & $<0.1$ & $<0.1$ & $<0.2$ & $<0.1$ & $<0.2$ & $<0.2$ & $<0.1$ \\
\hline WN 593 & $<0.1$ & $<0.1$ & $<0.1$ & $<0.2$ & $<0.1$ & $<0.2$ & $<0.2$ & $<0.1$ \\
\hline YT 585 & $<0.1$ & $<0.1$ & $<0.1$ & $<0.2$ & $<0.1$ & $<0.2$ & $<0.2$ & $<0.1$ \\
\hline \multicolumn{9}{|c|}{ Bedrock wells } \\
\hline CM 949 & $<0.1$ & $<0.1$ & $<0.1$ & $<0.2$ & $<0.1$ & $<0.2$ & $<0.2$ & $<0.1$ \\
\hline CY 266 & $<0.1$ & $<0.1$ & $<0.1$ & $<0.2$ & 0.4 & $<0.2$ & Е 0.1 & 3.7 \\
\hline CY 380 & $<0.1$ & $<0.1$ & $<0.1$ & $<0.2$ & $<0.1$ & $<0.2$ & $<0.2$ & $<0.1$ \\
\hline L 304 & $<0.1$ & $<0.1$ & $<0.1$ & $<0.2$ & $<0.1$ & $<0.2$ & $<0.2$ & $<0.1$ \\
\hline M 290 & $<0.1$ & $<0.1$ & $<0.1$ & $<0.2$ & $<0.1$ & $<0.2$ & $<0.2$ & $<0.1$ \\
\hline OD 830 & $<0.1$ & $<0.1$ & $<0.1$ & $<0.2$ & $<0.1$ & $<0.2$ & $<0.2$ & $<0.1$ \\
\hline OD 1366 & $<0.1$ & $<0.1$ & $<0.1$ & $<0.2$ & $<0.1$ & $<0.2$ & $<0.2$ & $<0.1$ \\
\hline OD 1870 & $<0.1$ & $<0.1$ & $<0.1$ & $<0.2$ & $<0.1$ & $<0.2$ & $<0.2$ & $<0.1$ \\
\hline OD 1900 & $<0.1$ & $<0.1$ & $<0.1$ & $<0.2$ & $<0.1$ & $<0.2$ & $<0.2$ & 0.7 \\
\hline OT 1480 & $<0.1$ & $<0.1$ & $<0.1$ & $<0.2$ & $<0.1$ & $<0.2$ & $<0.2$ & $<0.1$ \\
\hline OW 798 & $<0.1$ & $<0.1$ & $<0.1$ & $<0.2$ & $<0.1$ & $<0.2$ & $<0.2$ & $<0.1$ \\
\hline SE 794 & $<0.1$ & $<0.1$ & $<0.1$ & $<0.2$ & $<0.1$ & $<0.2$ & $<0.2$ & $<0.1$ \\
\hline SY 1064 & $<0.1$ & $<0.1$ & $<0.1$ & $<0.2$ & $<0.1$ & $<0.2$ & $<0.2$ & $<0.1$ \\
\hline TM 1018 & $<0.1$ & $<0.1$ & $<0.1$ & $<0.2$ & $<0.1$ & $<0.2$ & $<0.2$ & $<0.1$ \\
\hline TM 2448 & $<0.1$ & $<0.1$ & $<0.1$ & $<0.2$ & $<0.1$ & $<0.2$ & $<0.2$ & $<0.1$ \\
\hline WN 814 & $<0.1$ & $<0.1$ & $<0.1$ & $<0.2$ & $<0.1$ & $<0.2$ & $<0.2$ & $<0.1$ \\
\hline WN 847 & $<0.1$ & $<0.1$ & $<0.1$ & $<0.2$ & $<0.1$ & $<0.2$ & $<0.2$ & $<0.1$ \\
\hline YT 515 & $<0.1$ & $<0.1$ & $<0.1$ & $<0.2$ & $<0.1$ & $<0.2$ & $<0.2$ & $<0.1$ \\
\hline
\end{tabular}


Table A8. Concentrations of volatile organic compounds in groundwater samples from the central New York study area, 2007.-Continued

[Well locations are shown in figure 1. Well No.: Prefix denotes county: C, Cortland; CM, Chemung; CY, Cayuga; L, Lewis; M, Madison; MO, Monroe; OD, Onondaga; OE, Oneida; OT, Ontario, OW, Oswego; SE, Seneca; SY, Schuyler; TM, Tompkins; WN, Wayne; YT, Yates; number is local well-identification number assigned by U.S. Geological Survey. $\mu \mathrm{g} / \mathrm{L}$, micrograms per liter; <, less than; (34371), USGS National Water Information System parameter code; E, estimated value-constituent was detected in the sample but with low or inconsistent recovery. Bold values exceed one or more drinking-water standards]

\begin{tabular}{|c|c|c|c|c|c|c|c|c|}
\hline $\begin{array}{l}\text { Well } \\
\text { No. }\end{array}$ & $\begin{array}{c}\text { Ethyl- } \\
\text { benzene, } \\
\text { unfiltered, } \\
\mu \mathrm{g} / \mathrm{L} \\
(\mathbf{3 4 3 7 1 )}\end{array}$ & $\begin{array}{c}\text { Benzene } \\
\text { unfiltered, } \\
\mu \mathrm{g} / \mathrm{L} \\
\mathbf{( 3 4 0 3 0 )}\end{array}$ & $\begin{array}{c}\text { Toluene, } \\
\text { unfiltered, } \\
\mu \mathrm{g} / \mathrm{L} \\
(34010)\end{array}$ & $\begin{array}{c}m-+p- \\
\text { Xylene, } \\
\text { unfiltered, } \\
\mu g / L \\
(85795)\end{array}$ & $\begin{array}{c}\text { o-Xylene, } \\
\text { unfiltered, } \\
\mu \mathrm{g} / \mathrm{L} \\
(77135)\end{array}$ & $\begin{array}{c}\text { cis-1,2 Dichloro- } \\
\text { ethene, } \\
\text { unfiltered, } \\
\mu \mathrm{g} / \mathrm{L} \\
(77093)\end{array}$ & $\begin{array}{c}\text { Trichloro- } \\
\text { ethene, } \\
\text { unfiltered, } \\
\mu \mathrm{g} / \mathrm{L} \\
(39180)\end{array}$ & $\begin{array}{c}\text { Tetrachloro- } \\
\text { ethene, } \\
\text { unfiltered, } \\
\mu \mathrm{g} / \mathrm{L} \\
(34475)\end{array}$ \\
\hline \multicolumn{9}{|c|}{ Sand and gravel wells } \\
\hline C 1461 & $<0.1$ & $<0.1$ & $<0.1$ & $<0.2$ & $<0.1$ & $<0.1$ & $<0.1$ & $<0.1$ \\
\hline CY 10 & $<0.1$ & $<0.1$ & $<0.1$ & $<0.2$ & $<0.1$ & $<0.1$ & $<0.1$ & $<0.1$ \\
\hline CY 265 & $<0.1$ & $<0.1$ & $<0.1$ & $<0.2$ & $<0.1$ & $<0.1$ & $<0.1$ & $<0.1$ \\
\hline CY 995 & $<0.1$ & $<0.1$ & 0.8 & $<0.2$ & $<0.1$ & $<0.1$ & $<0.1$ & $<0.1$ \\
\hline M 291 & $<0.1$ & $<0.1$ & 0.2 & $<0.2$ & $<0.1$ & $<0.1$ & $<0.1$ & $<0.1$ \\
\hline MO 1560 & $<0.1$ & $<0.1$ & $<0.1$ & $<0.2$ & $<0.1$ & $<0.1$ & $<0.1$ & $<0.1$ \\
\hline OE 1465 & $<0.1$ & $<0.1$ & $<0.1$ & $<0.2$ & $<0.1$ & $<0.1$ & $<0.1$ & $<0.1$ \\
\hline OE 2848 & $<0.1$ & $<0.1$ & 0.1 & $<0.2$ & $<0.1$ & $<0.1$ & $<0.1$ & $<0.1$ \\
\hline OT 1864 & $<0.1$ & $<0.1$ & $<0.1$ & $<0.2$ & $<0.1$ & $<0.1$ & $<0.1$ & $<0.1$ \\
\hline OW 454 & $<0.1$ & $<0.1$ & $<0.1$ & $<0.2$ & $<0.1$ & $<0.1$ & $<0.1$ & 1.5 \\
\hline OW 503 & $<0.1$ & $<0.1$ & $<0.1$ & $<0.2$ & $<0.1$ & $<0.1$ & $<0.1$ & $<0.1$ \\
\hline SE 828 & $<0.1$ & $<0.1$ & $<0.1$ & $<0.2$ & $<0.1$ & $<0.1$ & $<0.1$ & $<0.1$ \\
\hline SE 1017 & $<0.1$ & $<0.1$ & 0.3 & $<0.2$ & $<0.1$ & $<0.1$ & $<0.1$ & $<0.1$ \\
\hline SY 402 & $<0.1$ & $<0.1$ & $<0.1$ & $<0.2$ & $<0.1$ & $<0.1$ & $<0.1$ & $<0.1$ \\
\hline TM 2355 & $<0.1$ & $<0.1$ & $<0.1$ & $<0.2$ & $<0.1$ & $<0.1$ & $<0.1$ & $<0.1$ \\
\hline WN 593 & $<0.1$ & $<0.1$ & $<0.1$ & $<0.2$ & $<0.1$ & $<0.1$ & $<0.1$ & $<0.1$ \\
\hline YT 585 & $<0.1$ & $<0.1$ & $<0.1$ & $<0.2$ & $<0.1$ & $<0.1$ & $<0.1$ & $<0.1$ \\
\hline \multicolumn{9}{|c|}{ Bedrock wells } \\
\hline CM 949 & $<0.1$ & $<0.1$ & $<0.1$ & $<0.2$ & $<0.1$ & $<0.1$ & $<0.1$ & $<0.1$ \\
\hline CY 266 & $<0.1$ & $<0.1$ & $<0.1$ & $<0.2$ & $<0.1$ & $<0.1$ & $<0.1$ & $<0.1$ \\
\hline CY 380 & $<0.1$ & $<0.1$ & $<0.1$ & $<0.2$ & $<0.1$ & $<0.1$ & $<0.1$ & $<0.1$ \\
\hline L 304 & $<0.1$ & $<0.1$ & $<0.1$ & $<0.2$ & $<0.1$ & $<0.1$ & $<0.1$ & $<0.1$ \\
\hline M 290 & $<0.1$ & $<0.1$ & 0.4 & $<0.2$ & $<0.1$ & $<0.1$ & $<0.1$ & $<0.1$ \\
\hline OD 830 & $<0.1$ & $<0.1$ & $<0.1$ & $<0.2$ & $<0.1$ & $<0.1$ & $<0.1$ & $<0.1$ \\
\hline OD 1366 & $<0.1$ & $<0.1$ & 0.1 & $<0.2$ & $<0.1$ & $<0.1$ & $<0.1$ & $<0.1$ \\
\hline OD 1870 & $<0.1$ & $<0.1$ & $<0.1$ & $<0.2$ & $<0.1$ & $<0.1$ & $<0.1$ & $<0.1$ \\
\hline OD 1900 & $<0.1$ & $<0.1$ & $<0.1$ & $<0.2$ & $<0.1$ & $<0.1$ & $<0.1$ & $<0.1$ \\
\hline OT 1480 & $<0.1$ & $<0.1$ & $<0.1$ & $<0.2$ & $<0.1$ & $<0.1$ & $<0.1$ & $<0.1$ \\
\hline OW 798 & $<0.1$ & $<0.1$ & $<0.1$ & $<0.2$ & $<0.1$ & $<0.1$ & $<0.1$ & $<0.1$ \\
\hline SE 794 & $<0.1$ & $<0.1$ & $<0.1$ & $<0.2$ & $<0.1$ & 0.4 & 50.8 & $<0.1$ \\
\hline SY 1064 & $<0.1$ & $<0.1$ & 0.2 & $<0.2$ & $<0.1$ & $<0.1$ & $<0.1$ & $<0.1$ \\
\hline TM 1018 & $<0.1$ & $<0.1$ & $<0.1$ & $<0.2$ & $<0.1$ & $<0.1$ & $<0.1$ & $<0.1$ \\
\hline TM 2448 & $<0.1$ & $<0.1$ & 1.0 & $<0.2$ & $<0.1$ & $<0.1$ & $<0.1$ & $<0.1$ \\
\hline WN 814 & $<0.1$ & $<0.1$ & $<0.1$ & $<0.2$ & $<0.1$ & $<0.1$ & $<0.1$ & $<0.1$ \\
\hline WN 847 & $<0.1$ & $<0.1$ & $<0.1$ & $<0.2$ & $<0.1$ & $<0.1$ & $<0.1$ & $<0.1$ \\
\hline YT 515 & 0.1 & 0.3 & 0.7 & 1.4 & 0.4 & $<0.1$ & $<0.1$ & $<0.1$ \\
\hline
\end{tabular}


Table A9. Concentrations of bacteria in unfiltered groundwater samples from the central New York study area, 2007.

[Well locations are shown in figure 1. Well No.: Prefix denotes county: C, Cortland; CM, Chemung; CY, Cayuga; L, Lewis; M, Madison; MO, Monroe; OD, Onondaga; OE, Oneida; OT, Ontario, OW, Oswego; SE, Seneca; SY, Schuyler; TM, Tompkins; WN, Wayne; YT, Yates; number is local well-identification number assigned by U.S. Geological Survey. mL, milliliter; <, less than; > greater than; CFU, colony-forming unit; (61213), National Water Information System (NWIS) parameter code. Bold values exceed one or more drinking-water standards]

\begin{tabular}{|c|c|c|c|c|}
\hline $\begin{array}{c}\text { Well } \\
\text { No. }\end{array}$ & $\begin{array}{c}\text { Total coliform } \\
\text { colonies per } 100 \mathrm{~mL} \\
(61213)\end{array}$ & $\begin{array}{c}\text { Fecal coliform } \\
\text { colonies per } 100 \mathrm{~mL} \\
(61215)\end{array}$ & $\begin{array}{c}\text { Escherichia coli, } \\
\text { colonies per } 100 \mathrm{~mL} \\
(31691)\end{array}$ & $\begin{array}{l}\text { Heterotrophic plate count, } \\
\text { CFUs per } \mathrm{mL} \\
\text { (31692) }\end{array}$ \\
\hline \multicolumn{5}{|c|}{ Sand and gravel wells } \\
\hline C 1461 & $<1$ & $<1$ & $<1$ & 10 \\
\hline CY 10 & $<1$ & $<1$ & $<1$ & 4 \\
\hline CY 265 & $<1$ & $<1$ & $<1$ & 1 \\
\hline CY 995 & $>200$ & $<1$ & $<1$ & 269 \\
\hline M 291 & 8 & $<1$ & $<1$ & 9 \\
\hline MO 1560 & 11 & $<1$ & $<1$ & 41 \\
\hline OE 1465 & $<1$ & $<1$ & $<1$ & $<1$ \\
\hline OE 2848 & $<1$ & $<1$ & $<1$ & 4 \\
\hline OT 1864 & $<1$ & $<1$ & $<1$ & 10 \\
\hline OW 454 & $<1$ & $<1$ & $<1$ & 2 \\
\hline OW 503 & $<1$ & $<1$ & $<1$ & 6 \\
\hline SE 828 & $>200$ & $<1$ & $<1$ & 92 \\
\hline SE 1017 & $<1$ & $<1$ & $<1$ & 100 \\
\hline SY 402 & $<1$ & $<1$ & $<1$ & 1 \\
\hline TM 2355 & $<1$ & $<1$ & $<1$ & 4 \\
\hline WN 593 & 26 & $<1$ & $<1$ & 6 \\
\hline YT 585 & 1 & $<1$ & $<1$ & 4 \\
\hline \multicolumn{5}{|c|}{ Bedrock wells } \\
\hline CM 949 & $<1$ & $<1$ & $<1$ & 19 \\
\hline CY 266 & 88 & $<1$ & $<1$ & 926 \\
\hline CY 380 & 21 & $<1$ & $<1$ & 27 \\
\hline L 304 & 2 & $<1$ & $<1$ & 8 \\
\hline M 290 & $>200$ & $<1$ & $<1$ & 1,780 \\
\hline OD 830 & 2 & $<1$ & $<1$ & 3 \\
\hline OD 1366 & $>200$ & 2 & $<1$ & 120 \\
\hline OD 1870 & 50 & $<1$ & $<1$ & 313 \\
\hline OD 1900 & $<1$ & $<1$ & $<1$ & 6 \\
\hline OT 1480 & 25 & $<1$ & $<1$ & 7 \\
\hline OW 798 & 2 & $<1$ & $<1$ & 22 \\
\hline SE 794 & $>200$ & $<1$ & $<1$ & 13 \\
\hline SY 1064 & 10 & $<1$ & $<1$ & 26 \\
\hline TM 1018 & $<1$ & $<1$ & $<1$ & 5 \\
\hline TM 2448 & 31 & $<1$ & $<1$ & 6,880 \\
\hline WN 814 & 98 & $<1$ & $<1$ & 26 \\
\hline WN 847 & $<1$ & $<1$ & $<1$ & 23 \\
\hline YT 515 & $<1$ & $<1$ & $<1$ & 4 \\
\hline
\end{tabular}


Prepared by the Pembroke, W. Trenton, and Tacoma Publishing Service Centers.

For more information concerning this report, contact:

\section{Director}

U.S. Geological Survey

New York Water Science Center

425 Jordan Road

Troy, NY 12180-8349

dc_ny@usgs.gov

or visit our Web site at:

http://ny.water.usgs.gov 


\section{总}

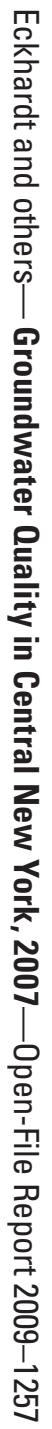

